\title{
Fc-Mediated Antibody Effector Functions During Respiratory Syncytial Virus Infection and Disease
}

OPEN ACCESS

Edited by:

Guido Ferrari,

Duke University, United States

Reviewed by:

Stephen Kent,

The University of Melbourne, Australia

George Kenneth Lewis,

University of Maryland, United States

*Correspondence:

Puck B. van Kasteren puck.van.kasteren@rivm.n

Specialty section:

This article was submitted to

Comparative Immunology,

a section of the journal

Frontiers in Immunology

Received: 26 October 2018

Accepted: 28 February 2019

Published: 22 March 2019

Citation:

van Erp EA, Luytjes W, Ferwerda G and van Kasteren PB (2019)

FC-Mediated Antibody Effector Functions During Respiratory Syncytial

Virus Infection and Disease.

Front. Immunol. 10:548

doi: 10.3389/fimmu.2019.00548
Elisabeth A. van Erp ${ }^{1,2,3}$, Willem Luytjes ${ }^{1}$, Gerben Ferwerda ${ }^{2,3}$ and Puck B. van Kasteren ${ }^{\text {1* }}$

${ }^{1}$ Centre for Infectious Disease Control, National Institute for Public Health and the Environment (RIVM), Bilthoven, Netherlands, ${ }^{2}$ Section Pediatric Infectious Diseases, Laboratory of Medical Immunology, Radboud Institute for Molecular Life Sciences, Nijmegen, Netherlands, ${ }^{3}$ Radboud Center for Infectious Diseases, Nijmegen, Netherlands

Respiratory syncytial virus (RSV) is a major cause of severe lower respiratory tract infections and hospitalization in infants under 1 year of age and there is currently no market-approved vaccine available. For protection against infection, young children mainly depend on their innate immune system and maternal antibodies. Traditionally, antibody-mediated protection against viral infections is thought to be mediated by direct binding of antibodies to viral particles, resulting in virus neutralization. However, in the case of RSV, virus neutralization titers do not provide an adequate correlate of protection. The current lack of understanding of the mechanisms by which antibodies can protect against RSV infection and disease or, alternatively, contribute to disease severity, hampers the design of safe and effective vaccines against this virus. Importantly, neutralization is only one of many mechanisms by which antibodies can interfere with viral infection. Antibodies consist of two structural regions: a variable fragment (Fab) that mediates antigen binding and a constant fragment $(\mathrm{FC})$ that mediates downstream effector functions via its interaction with Fc-receptors on (innate) immune cells or with $\mathrm{C} 1 \mathrm{q}$, the recognition molecule of the complement system. The interaction with Fc-receptors can lead to killing of virus-infected cells through a variety of immune effector mechanisms, including antibody-dependent cell-mediated cytotoxicity (ADCC) and antibody-dependent cellular phagocytosis (ADCP). Antibody-mediated complement activation may lead to complement-dependent cytotoxicity (CDC). In addition, both Fc-receptor interactions and complement activation can exert a broad range of immunomodulatory functions. Recent studies have emphasized the importance of Fc-mediated antibody effector functions in both protection and pathogenesis for various infectious agents. In this review article, we aim to provide a comprehensive overview of the current knowledge on Fc-mediated antibody effector functions in the context of RSV infection, discuss their potential role in establishing the balance between protection and pathogenesis, and point out important gaps in our understanding of these processes. Furthermore, we elaborate on the regulation of these effector functions on both the cellular and humoral side. Finally, we discuss the implications of Fc-mediated antibody effector functions for the rational design of safe and effective vaccines and monoclonal antibody therapies against RSV.

Keywords: RSV, antibody, Fc gamma receptor, Fc-mediated effector functions, antibody functionality, ADCC, ADCP, vaccine 


\section{INTRODUCTION}

Respiratory syncytial virus (RSV) infection is a major cause of severe respiratory illness requiring hospitalization in young infants (1). Hospitalization for severe RSV-mediated disease peaks between 6 weeks and 6 months of life $(2,3)$, when infants mainly depend on their innate immune system and maternal antibodies for protection against infectious diseases. However, the exact role of RSV-specific maternal antibodies is unclear. Some studies show that high titers of maternal antibodies are associated with protection against RSV infection (4-6); whereas others indicate that high maternal antibody titers do not have a beneficial effect or even associate with an increased risk of recurrent wheezing (7-11). It is important to note that the antibody titers in these studies are determined by in vitro binding or neutralization assays, while additional antibody effector functions are not taken into account.

For nearly all licensed vaccines, antibodies are the presumed correlate of protection, but the underlying mechanisms of protection often remain unknown (12). Recent research suggests that, in addition to binding and neutralization, antibody effector functions are important contributors to protective immunity against several viruses, including influenza virus (13-15), HIV $(16,17)$, and Ebola virus $(18,19)$.

In contrast to their beneficial role in providing protection against infection and disease, antibodies have also been implicated in disease enhancement. For example, nonneutralizing dengue-specific antibodies have been shown to mediate antibody-dependent enhancement (ADE) of disease $(20,21)$. Interestingly, the 1960's formalin-inactivated (FI) RSV vaccine induced poorly-neutralizing antibodies which have been suggested to be involved in vaccine-enhanced disease upon natural infection (22-24). These examples illustrate the possibility that virus-specific antibodies contribute to pathogenesis when failing to protect.

Currently, the RSV field lacks a comprehensive overview of antibody effector functions in the context of RSV infection and disease. Here, we review what is known about various antibody effector functions during RSV infection, discuss their potential role in establishing the balance between protection and pathogenesis, and point out important gaps in our understanding of these processes. Moreover, we elaborate on the regulation of these effector functions on both the cellular and humoral side. Finally, we discuss the implications of antibody-mediated effector functions for the rational design of safe and effective vaccines and monoclonal antibody therapies against RSV. A thorough understanding of the role of antibodies in protection or disease during RSV infection is crucial for the development of new and improved vaccination strategies and may provide much-needed new insights into the precise mechanisms of antibody-mediated protective immunity.

\section{FC-MEDIATED ANTIBODY EFFECTOR FUNCTIONS}

Antibody effector functions are an important part of the humoral immune response and form an essential link between innate and adaptive immunity. Most of these effector functions are induced via the constant $(\mathrm{Fc})$ region of the antibody, which can interact with complement proteins and specialized Fc-receptors. The latter can induce activating or inhibitory pathways, depending on the type of receptor, and are found on B cells and most innate immune cells in various combinations. The most well-known Fc-mediated antibody effector functions are antibody-dependent cell-mediated cytotoxicity (ADCC), antibody-dependent cellular phagocytosis (ADCP), and complement-dependent cytotoxicity (CDC). In addition, antibodies have been found to mediate inflammation and immunomodulation through the induction of cellular differentiation and activation. Each of these functions is described in detail below and a schematic overview is depicted in Figure 1.

\section{ANTIBODY-DEPENDENT CELL-MEDIATED CYTOTOXICITY (ADCC)}

ADCC is induced when Fc gamma receptors ( $\mathrm{Fc} \gamma \mathrm{Rs}$ ) on innate effector cells are engaged by the Fc domain of antibodies that are bound to viral proteins on the surface of virus-infected cells. This interaction induces the release of cytotoxic granules (containing perforins and granzymes) resulting in killing of infected cells (25). Multiple innate effector cells, including natural killer (NK) cells, neutrophils, monocytes, and macrophages, are capable of $\mathrm{ADCC}$ in vitro. However, the most important contributors to ADCC in vivo are thought to be NK cells, which express only Fc $\gamma$ RIIIA. Figure 2 shows a schematic representation of ADCC.

In the field of tumor immunology, ADCC has been recognized as an important mechanism of action for therapeutic monoclonal antibodies (mAbs) that target tumor cells [as reviewed by (26)]. For infectious diseases, ADCC only recently started to gain attention. ADCC has been shown to form a critical component of effective immunity against HIV and influenza virus. ADCC-inducing HIV-specific antibodies were identified as a key correlate of protection in the RV144 HIV vaccine trial (27-29). Moreover, HIV-infected individuals who control the virus without antiretroviral therapy demonstrated a broader polyfunctional humoral immune response including ADCC activity compared to viremic individuals (30-33). There has been much debate about the role of ADCC during influenza-induced disease. Some studies point to the protective capacity of ADCCinducing antibodies $(34,35)$, whereas others do not show any role for NK cells in antibody-mediated protection (36), or even suggest involvement of ADCC in exaggeration of the immune response (37-39). For multiple other clinically important viral infections, including dengue virus and Ebola virus, research into the effect of ADCC is ongoing (40-42). Taken together, ADCC seems to be involved in the immune response against multiple viruses and is therefore potentially of interest in the context of RSV infection.

\section{ADCC in RSV Infection}

NK cells are the most important contributors to ADCC in vivo and important effector cells during RSV infection. In mice, increased numbers of NK cells are present in the lungs early after RSV infection (43-45). In RSV-infected infants, the 


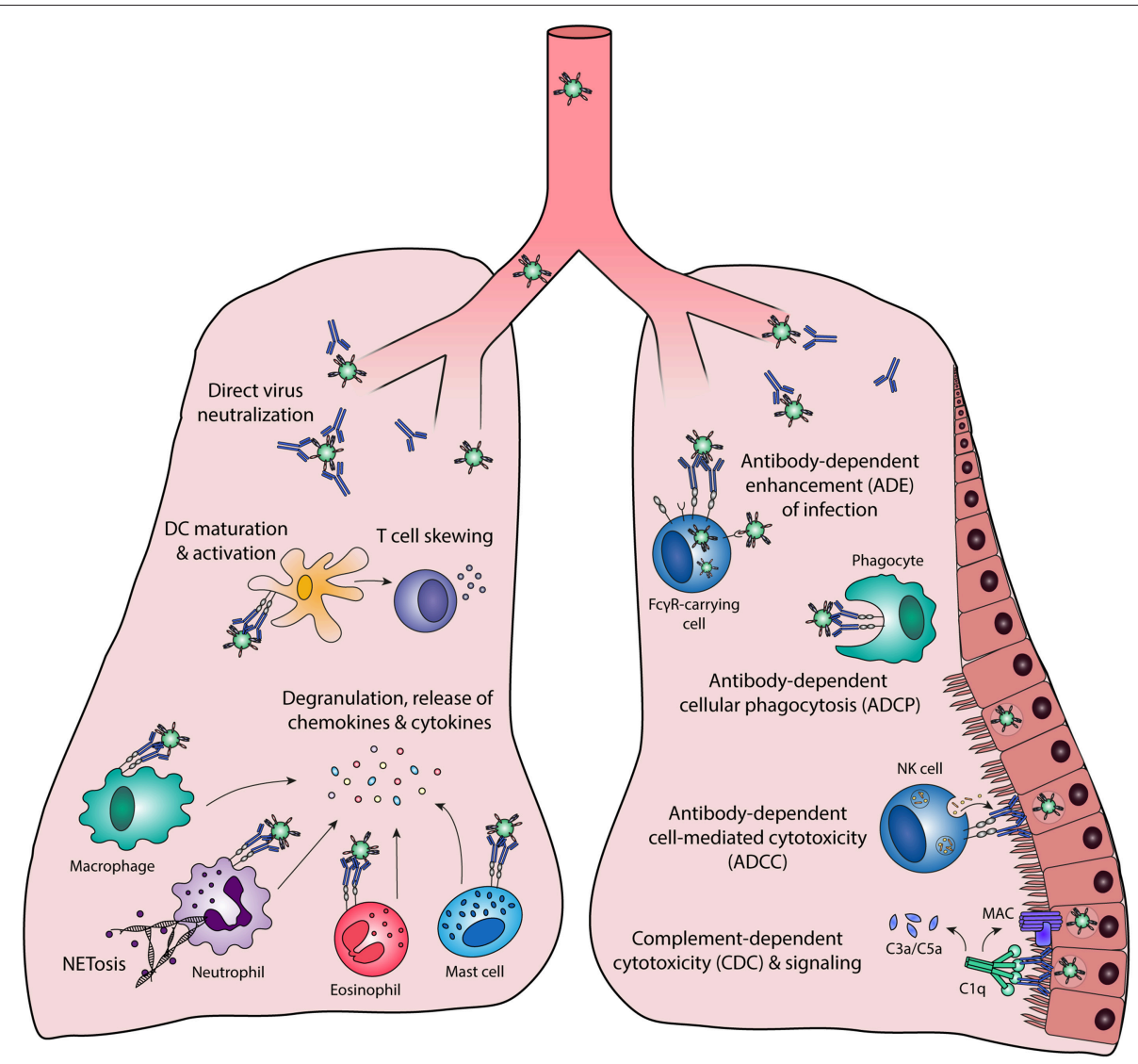

FIGURE 1 | Fc-mediated antibody effector functions. Antibodies elicit a wide range of effector functions during viral infections. These include but are not necessarily limited to the functions depicted in this figure. DC, dendritic cell; Fc $\gamma$ R, Fc gamma receptor; MAC, membrane attack complex; NK cell, natural killer cell.

proportion of NK cells has been reported both to be decreased $(46-49)$ or increased $(50,51)$ in comparison with healthy controls or infants with mild symptoms. Since maternallyderived antibodies are virtually always present during primary RSV infection and antibody-coated virus-infected cells are a trigger for ADCC, it can be assumed that ADCC occurs during primary RSV infection.

Although NK cells are thought to be the most important mediators of ADCC against virus-infected cells, this has never been shown for RSV. All studies mentioned below are performed with peripheral blood mononuclear cells (PBMCs), without distinction between different cell types. RSV-specific immunoglobulin G (IgG) has been shown to induce ADCC toward RSV-infected epithelial cells in vitro $(52,53)$. The major surface antigens of RSV are the fusion (F) and the attachment $(\mathrm{G})$ protein which are both required for infectivity in vivo. The RSV F protein has two conformational states: postfusion (post-F) and pre-fusion (pre-F), of which the latter is a potent target for neutralization (54). Multiple studies show that anti-RSV G antibodies are efficient inducers of ADCC in vitro $(55,56)$, and the involvement of this process in virus clearance in vivo has been proposed $(57,58)$. In contrast, anti-RSV $\mathrm{F}$ antibodies do not efficiently induce ADCC in vitro (55), although it must be noted that no distinction between pre- and post-F antibodies was made and the ADCC potential could differ between the two functional states of the F protein.

Antibodies from breast milk, cord blood, and nasopharyngeal secretions and serum from RSV-infected infants show ADCC activity in vitro $(52,53,59)$. This shows that the antibodies that are present in vivo are capable of eliciting ADCC activity in vitro. Two studies showed that the level of ADCC activity measured in vitro was independent of clinical symptoms and age, suggesting that ADCC is not a determining factor in the varying clinical manifestations of primary RSV infection $(53,59)$. Interestingly, the ADCC capacity of serum antibodies from RSV-infected infants rapidly declines over time, whereas the neutralization capacity remains more stable. If ADCC is important in protection against infection, this decline could partly explain the susceptibility to repeated infections throughout life.

Limited evidence is present on the occurrence of ADCC during RSV infection in vivo. The most convincing data is provided by mouse studies performed with anti-RSV G proteinspecific Fab- or $\mathrm{F}\left(\mathrm{ab}^{\prime}\right)_{2}$ fragments lacking the complete $\mathrm{Fc}$ domain, or aglycosylated antibodies lacking the glycosylation site 


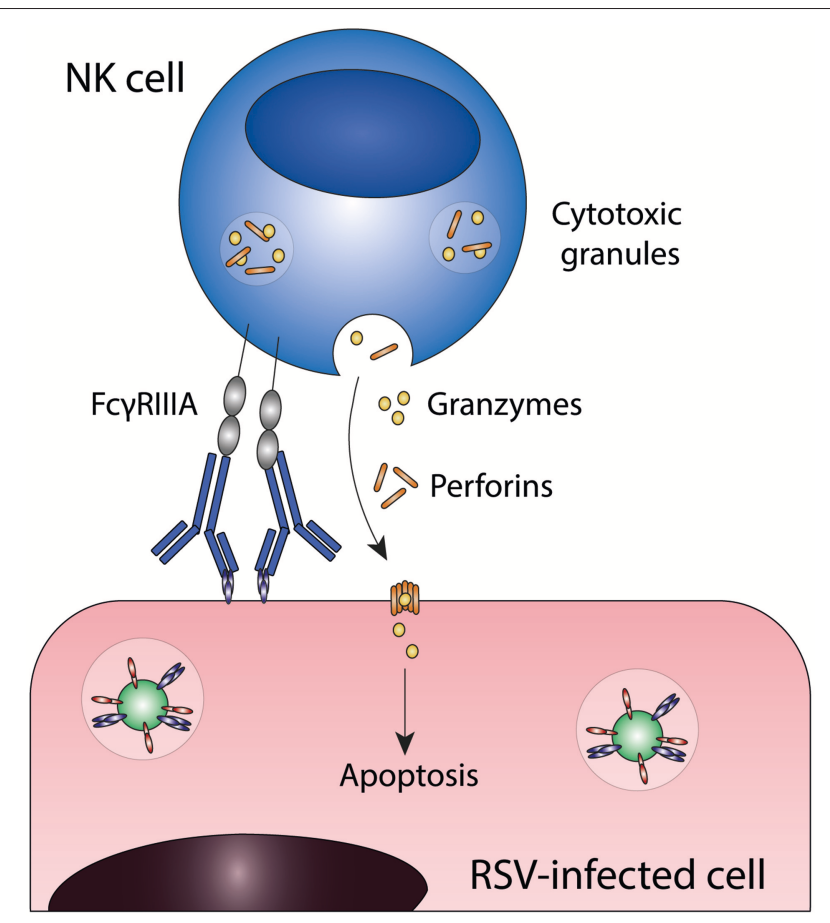

FIGURE 2 | Antibody-dependent cell-mediated cytotoxicity (ADCC). FC gamma receptors present on for example natural killer (NK) cells engage antibody-bound infected cells and induce target cell death through the release of cytotoxic granules. Fc $\gamma$ RIIIA, Fc gamma receptor IIIA; NK cell, natural killer cell; RSV, respiratory syncytial virus. that is required for efficient $\mathrm{Fc} \gamma \mathrm{R}$ and complement interactions $(58,60,61)$. It was shown that Fab fragments of the 1812A2B anti-RSV $G$ antibody and $F(a b)_{2}$ fragments of the 131-2G anti-RSV G antibody do not reduce viral load, whereas the corresponding intact antibodies do confer protection $(58,60)$. The authors propose that virus clearance by the $131-2 \mathrm{G}$ antibody is mediated through ADCC, however, the involvement of other Fc-mediated effector functions in this study cannot be ruled out. In an attempt to ascertain the role of ADCC by NK cells in the protective mechanisms of the anti-RSV G antibody 18A2B2, SCID beige mice (which are deficient in NK cell activity) were passively immunized with the full antibody (60). In this study, the absence of NK cells had no effect on the protective capacity of 18A2B2, pointing to the involvement of other $\mathrm{Fc}$ effector functions. Further research is needed to study the exact role of ADCC for other mAbs and RSVimmune serum. Passive immunization with aglycosylated 1C2 anti-RSV G antibodies reduced virus titers significantly but were not as effective as wildtype antibodies, indicating that protection by the 1C2 antibody is mediated by both Fcdependent and Fc-independent mechanisms (61). Although these studies highlight the importance of Fc-mediated antibody effector functions in protection against RSV infection in the case of these specific anti-RSV G mAbs, the role of ADCC in protection or pathogenesis during natural RSV infection remains to be determined.

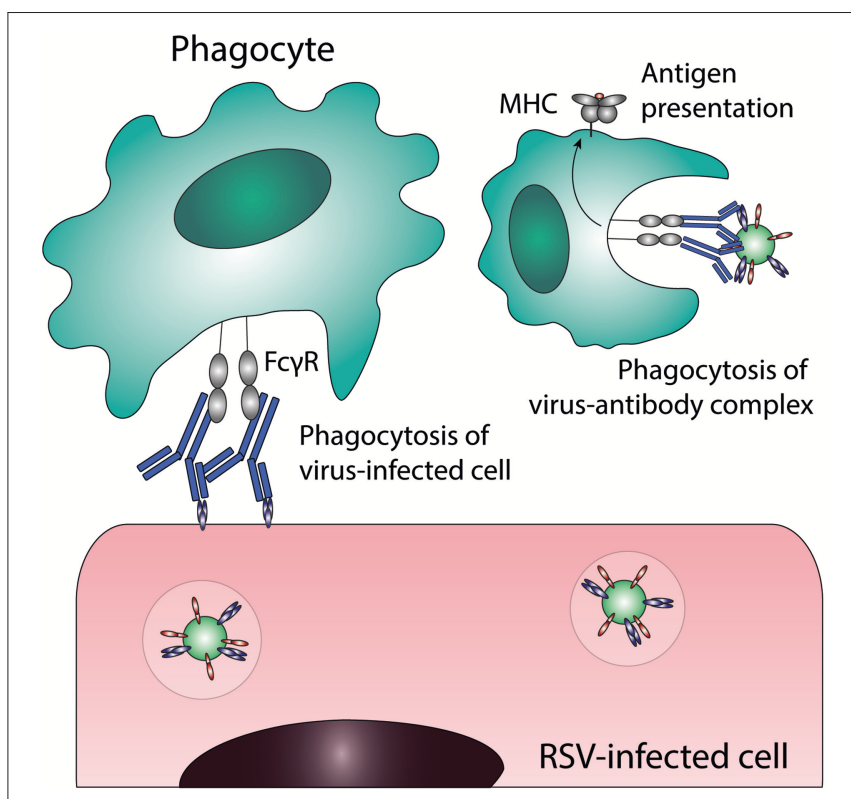

FIGURE 3 | Antibody-dependent cellular phagocytosis (ADCP). Phagocytes can clear virus-infected cells and immune complexes that are engaged by FC gamma receptors through phagocytosis. Uptake of viral particles or proteins leads to antigen presentation, which induces the adaptive immune system. Fc $\gamma$ R, Fc gamma receptor; MHC, major histocompatibility complex; RSV, respiratory syncytial virus.

\section{ANTIBODY-DEPENDENT CELLULAR PHAGOCYTOSIS (ADCP)}

ADCP or opsonophagocytosis is the uptake of virus-antibody complexes or antibody-coated virus-infected cells by phagocytic cells (for a schematic representation of this process see Figure 3). Phagocytic cells, including monocytes, macrophages, neutrophils, eosinophils and dendritic cells (DCs), express Fc $\gamma$ RI, Fc $\gamma$ RII, and FcoRI, which can all mediate immune complex uptake. The exact phagocytic capacity of effector leukocytes is dependent upon the cell type, differentiation stage, and level of $\mathrm{Fc} \gamma \mathrm{R}$ expression. ADCP results in the clearance of immune complexes from the infected host, by trafficking of the complexes to lysosomes for degradation and antigen processing for presentation on Major Histocompatibility Complex (MHC)molecules on the cell surface. Interestingly, some viruses have exploited this mechanism to infect phagocytes by escaping from lysosomal degradation (described below in "Antibody-dependent enhancement of infection").

ADCP has been extensively described for its role in protection against bacteria, but its importance during viral infections is unclear. Some studies have been performed for influenza virus, showing that phagocytosis by (alveolar) macrophages may contribute to protection from infection in mice $(36,62)$ and potentially plays a role in the recovery from severe infections in humans $(15,63)$. Also for cytomegalovirus (CMV), it was shown that vaccine-induced antibodies play an important role in vaccine efficacy, independent of neutralization or ADCC capacity (64). In accordance with these results, a study by Nelson et al. showed no 
role for neutralization or ADCC, while robust ADCP induction was observed (65). Antibody-mediated clearance by phagocytes in vivo has also been suggested for $\operatorname{HIV}(66,67)$, adenovirus (68), West Nile Virus (WNV) (69), and foot-and-mouth disease virus $(70,71)$.

\section{ADCP in RSV Infection}

Phagocytosis of RSV-antibody complexes or RSV-infected cells has to our knowledge never been directly explored as a protective immune mechanism for RSV. In vitro studies show phagocytosis of RSV immune complexes by neutrophils $(56,72,73)$ and eosinophils (74). Varying levels of phagocytic activity have been observed for different RSV-specific monoclonal antibodies, suggesting that ADCP activity depends on epitope and/or affinity $(56,73)$. An in vivo mouse study has shown that macrophages are essential in conferring antibody-mediated restriction of RSV replication, whereas neutrophil depletion did not significantly affect pulmonary viral replication (75). This suggests that Fcmediated effector functions executed by macrophages rather than neutrophils are important in protection against RSV infection in a mouse model.

Besides the uptake of viral particles, phagocytosis initiates the activation of cells. This can result in the release of a broad range of effector molecules (72-74), which will be described in detail in "Antibody-dependent immunomodulation during RSV infection." Although there is limited evidence on the role of ADCP during RSV infection, the importance of macrophages in antibody-mediated protection in mice provides a basis for further investigation.

\section{ANTIBODY-MEDIATED COMPLEMENT ACTIVATION}

Besides ADCC and ADCP, antibodies can also induce complement activation. The complement cascade contributes to pathogen elimination either directly, by means of complementdependent cytotoxicity (CDC), or indirectly, through phagocytic clearance of complement-coated targets and the induction of an inflammatory response. Activation of the classical complement pathway results from binding of the recognition molecule $\mathrm{C} 1 \mathrm{q}$ to the $\mathrm{Fc}$ domain of antibodies bound to virus-infected cells $(76,77)$, as depicted in Figure 4. Upon binding of C1q, the proteases of the classical pathway are activated, leading to cleavage of $\mathrm{C} 2$ and $\mathrm{C} 4$. Together, the resulting cleavage products form the $\mathrm{C} 3$ convertase $(\mathrm{C} 4 \mathrm{bC} 2 \mathrm{a})$ that cleaves $\mathrm{C} 3$ into $\mathrm{C} 3 \mathrm{a}$ and $\mathrm{C} 3 \mathrm{~b}$. One of the mechanisms by which the complement cascade is regulated, is cleavage of active $C 4 b$, which serves as a marker for complement activation. The release of anaphylatoxins C3a and C5a stimulates a pro-inflammatory environment by inducing the recruitment of immune effector cells and the activation of leukocytes, endothelial cells, epithelial cells, and platelets $(78,79)$. The highly reactive $\mathrm{C} 3 \mathrm{~b}$ binds to pathogens and infected cells, leading to immune complex clearance and phagocytosis through complement receptors found on immune cells. The terminal complement components will assemble into the membrane attack complex (MAC), resulting in lysis of the infected cell. Besides direct antiviral activity, the complement system can also regulate $\mathrm{B}$ cell responses. The binding of complement-coated immune complexes to complement receptor 2 on B cells is reported to lower the B cell activation threshold, thereby promoting long-lived adaptive immunity and higher antibody levels $(80,81)$.

Complement can have both a protective and pathogenic role during viral infections. The protective capacity of poorly neutralizing antibodies during WNV infection is mediated by the complement system, as was shown using knockout mice (69). The presence of complement even enhances the neutralization capacity of WNV-specific antibodies (82). In addition, an important role for complement has been shown in the protective capacity of (monoclonal) antibodies against influenza virus (38, 83), vaccinia virus (84), $\operatorname{CMV~(85),~and~} \operatorname{HIV}(66,67)$. In contrast, complement activation has also been suggested to contribute to disease severity in dengue virus $(86,87)$ and HIV infection $(88,89)$.

\section{Antibody-Mediated Complement Activation in RSV Infection}

The complement system consists of multiple components and elicits its effector functions through different pathways. Early studies have shown antibody and complement deposition on nasopharyngeal cells of RSV-infected infants (90). Whether this contributed to viral clearance or disease was not determined. Studies in complement-deficient mice have shown that complement is important in antibody-mediated protection against RSV infection $(60,75)$. A number of different mechanisms have been suggested for this complement-enhanced protection. Firstly, direct enhancement of the neutralization capacity of antibodies by fixation of complement components to virus-antibody complexes may increase the steric hindrance of bound antibodies (91). Another mechanism that could be at play is complement-dependent opsonization of virus-infected cells, which leads to subsequent uptake by phagocytes. Finally, complement has also been shown to increase the CD4(+) T cell response in the presence of RSV immune serum in an in vivo mouse model (92).

Besides its potential role in the clearance and/or pathogenesis of natural RSV infection, complement activation has been suggested to contribute to disease enhancement induced by natural infection following FI-RSV vaccination. C3a receptor (C3aR)-deficient mice had decreased airway hyperresponsiveness (AHR) and less mucus production in an FI-RSV vaccinationchallenge model (93). In this study, C3aR expression was enhanced in C5-knockout mice, showing that the balance in activation of different complement factors (C3a vs. C5a) is important in determining disease outcome. Moreover, Polack et al. demonstrated the co-localization of IgG and C3 in the lungs of mice with enhanced RSV disease, but not in control mice (22). In addition, both C3- and B cell-knockout mice showed a decrease in bronchoconstriction compared to WT mice vaccinated with FI-RSV. Therefore, in a mouse model of vaccineenhanced disease, the presence of C5 seems protective, whereas C3a promotes enhanced disease. This is also supported by the 


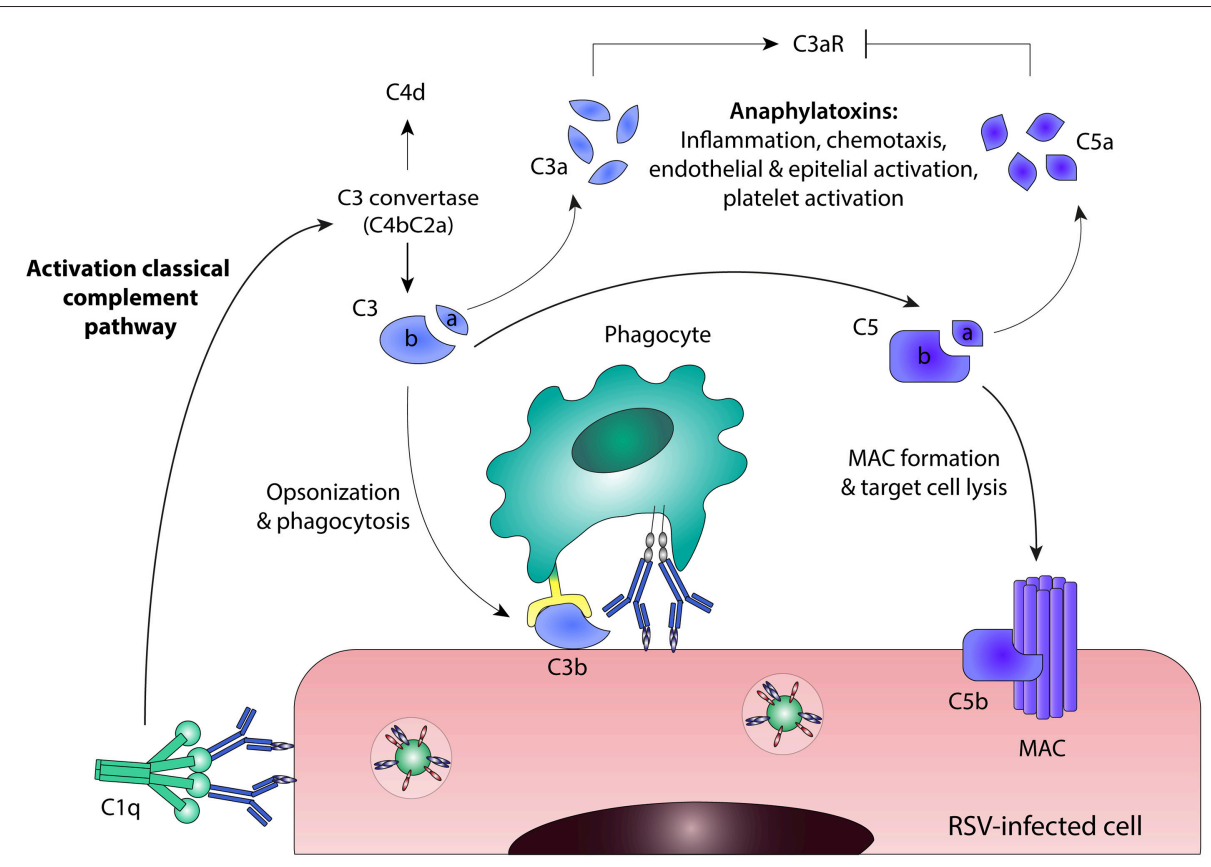

FIGURE 4 | Antibody-mediated complement activation. Binding of C1q to antibody-bound virus-infected cells leads to activation of the classical complement pathway. C3 convertase (C4bC2a) is formed and cleaves C3 into C3a and C3b. Active C4b can be cleaved into the enzymatically inactive form C4d, which serves as a marker for complement activation. Further downstream in the classical complement pathway, C5 is cleaved into C5a and C5b. C3a and C5a are anaphylatoxins that stimulate a pro-inflammatory environment, although they act in different ways: C3a induces C3aR signaling, whereas C5a inhibits C3aR expression. C3b binds to pathogens and infected cells, leading to phagocytosis through complement receptors found on immune cells. The terminal complement components will assemble into the membrane attack complex (MAC), resulting in direct lysis of the infected cell. C3aR, C3a Receptor; MAC, membrane attack complex; RSV, respiratory syncytial virus.

limited data available on complement activation during vaccineenhanced disease in infants. Lung sections of the two children who died of vaccine-enhanced disease had extensive deposition of complement cleavage product $\mathrm{C} 4 \mathrm{~d}$, which serves as a stable marker for complement activation (22). The presence of C4d provides evidence for complement activation during vaccineenhanced disease in infants, but it remains to be determined whether there is a causal relation between complement activation and vaccine-enhanced disease. Finally, mouse studies point to the involvement of complement components in the development of AHR and asthma upon RSV infection $(94,95)$. Taken together, the complement system seems to be important in antibodydependent protection in vivo, but it also potentially contributes to (vaccine-enhanced) disease and asthma, suggesting a dual role in RSV infection that requires further investigation.

\section{ANTIBODY-MEDIATED IMMUNOMODULATION}

Besides the well-defined classical Fc-mediated effector functions (ADCC, ADCP, CDC), immune complexes can also promote immune cell maturation and activation, leading to a wide range of effector activities and production of pro-inflammatory and immunomodulatory mediators (a limited overview is depicted in Figure 5). Some of these pro-inflammatory cytokine responses correlate with protection as has been shown for influenza (62) and HIV (96). The importance of Fc $\gamma$ Rs in this process has been shown by the use of Fc $\gamma$ R-deficient mice [as extensively reviewed in (97)]. In contrast to the pro-inflammatory responses caused by immune complexes, injection with intravenous immunoglobulin (IVIg) can induce an anti-inflammatory state. It is proposed that this anti-inflammatory effect is partly due to the presence of sialylated antibodies in IVIg, which induce expression of Fc $\gamma$ RIIB (the only inhibitory $\mathrm{F} c \gamma \mathrm{R}$ ) and thereby dampen the inflammatory response (98).

Immune complexes can also regulate cellular maturation and activation. The balance between inhibitory and activating Fc $\gamma \mathrm{R}$ interactions is crucial in regulating B cell IgG responses (99-101), and skewing APC maturation and antigen presentation (102105), which can modulate $T$ cell activation. Immune complexes have also been shown to bias the macrophage immune response toward a Th2-like phenotype (106).

\section{Antibody-Mediated Immunomodulation in RSV Infection}

RSV-antibody complexes can lead to activation of phagocytes either directly or after phagocytosis, resulting in the production of reactive oxygen species (ROS), thromboxane, (proinflammatory) cytokines, and chemokines (72, 73, 107), which may contribute to viral clearance. However, these mediators can also have immunopathological effects, including tissue damage, platelet aggregation, and bronchoconstriction. Given that neutrophils are the predominant airway leukocytes 

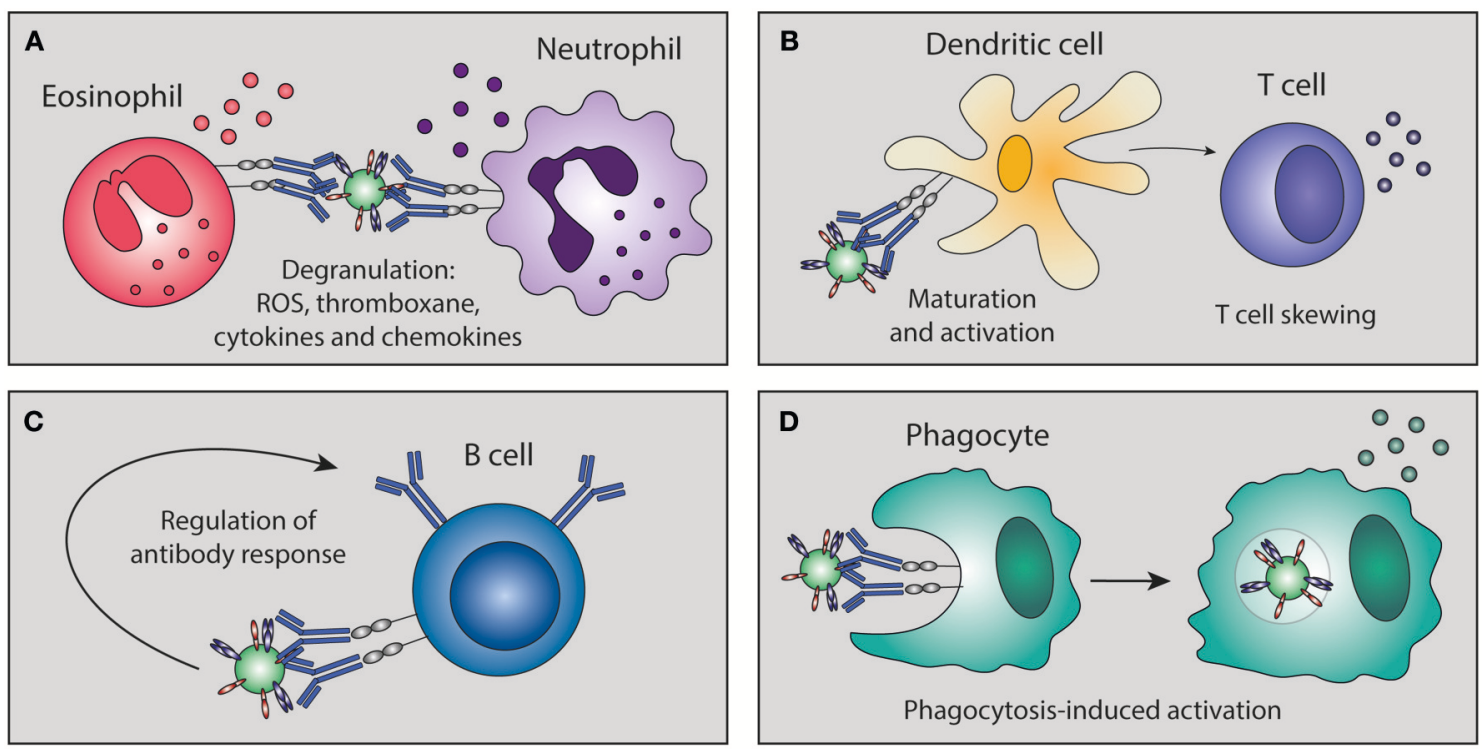

FIGURE 5 | Antibody-mediated immunomodulation. Immune complexes can skew immune cell maturation and activation of granulocytes, dendritic cells, T cells, B cells, and phagocytes. This immunomodulation can lead to (A) degranulation, (B) skewing of T cell responses, (C) regulation of B cell antibody responses, and (D) phagocytosis-induced secretion of immunomodulatory mediators. ROS, reactive oxygen species.

present in RSV-infected infants, their activation is suggested to be involved in the induction of severe RSV disease (108). Interestingly, in contrast to RSV immune complexes, it has been reported that RSV alone does not lead to ROS production by granulocytes (107) and can even inhibit this process $(73,109)$. It has been suggested that anti-RSV G mAbs are less potent inducers of ROS and cytokine production than anti-RSV F mAbs (73), but this was based on experiments with only two RSV-specific antibodies. Notably, differences in the capacity to induce a response may not be due to antigen-specificity per se but rather due to epitope localization, as described in the paragraph "Important epitopes in RSV infection."

Excessive eosinophilic activation has been suggested to play a role in the immunopathology of FI-RSV-induced disease in mice (22). Whether the non-neutralizing antibodies induced by the FI-RSV vaccine play a role in this activation remains unknown. In vitro studies have shown that eosinophils can phagocytose RSV-antibody complexes, leading to degranulation (74). The use of heat-inactivated serum abolished this effect, indicating complement involvement.

Besides an immunomodulatory effect on granulocytes, RSVantibody complexes can also affect $\mathrm{T}$ cell responses. Kruijsen et al. show in an in vivo mouse model that IFN- $\gamma$ secretion by CD4(+) T cells is increased in the presence of RSV immune serum (92). This increase is dependent on both Fc $\gamma$ Rs and the complement system. Additional in vitro experiments indicate that both anti-RSV G, as well as anti-RSV F antibodies can induce this enhanced CD4(+) $\mathrm{T}$ cell response, whereas CD8(+) $\mathrm{T}$ cells are only activated by the presence of anti-RSV G antibodies. Another in vitro study found that DCs primed with complexes composed of RSV and F-specific antibodies displayed an impaired capacity to activate CD8(+) and CD4(+) T cells (110).

RSV-antibody complexes also contribute to antibodymediated immunomodulation through the induction or inhibition of cytokine and chemokine production in PBMCs. In an in vitro study, RSV-antibody complexes inhibited IFN- $\alpha$ production in PBMCs, whereas these complexes enhanced IFN- $\alpha$ production of PBMCs in the absence of $\mathrm{CD} 14(+)$ cells (111). Another in vitro study showed that, compared to RSV alone, RSV immune complexes induce increased IFN- $\alpha$, IFN- $\gamma$, CXCL10, and CXCL11 production in monocytes (112). In infant PBMCs, only CXCL10 production was significantly enhanced. CXCL10 can mediate a neutrophil-dependent excessive pulmonary inflammation (113), which could contribute to RSV pathogenesis. This indicates that immune complexes can potentially also activate neutrophils indirectly, through the induction of chemokines and cytokines in PBMCs. Altogether, these studies show that immune complexes are able to skew the RSV-specific immune response in multiple ways, but more research is needed to clarify the exact contribution of antibodymediated immunomodulation to protection and disease during RSV infection.

\section{ANTIBODY-DEPENDENT ENHANCEMENT (ADE) OF INFECTION}

$\mathrm{ADE}$ refers to a phenomenon in which virus-specific antibodies promote, rather than inhibit, infection and/or disease. In $\mathrm{ADE}$ of infection, also known as extrinsic $\mathrm{ADE}$ (114), the number of virus-infected cells is increased in the 
presence of (natural or monoclonal) antibodies that are nonneutralizing or present in sub-neutralizing concentrations. $\mathrm{ADE}$ of infection requires the presence of $\mathrm{Fc} \gamma \mathrm{Rs}$ on target cells and is an efficient in vitro tool to assess Fc-Fc $\gamma \mathrm{R}$ interactions. However, while ADE of infection has been observed for many viruses in vitro [as extensively reviewed in (115)], its significance in vivo remains uncertain. A schematic representation of $\mathrm{ADE}$ of infection is depicted in Figure 6.

\section{ADE of RSV Infection}

$\mathrm{ADE}$ of RSV infection has been demonstrated in vitro for both $\mathrm{mAbs}$ and RSV-immune serum in monocytic cell lines, PBMCs, neonatal, and adult NK cells, and primary mouse and cotton rat immune cells (110, 116-120). However, whether the ADE of infection observed in vitro is related to in vivo disease outcome is doubtful. No correlation has been found between disease severity in infants and the capacity of serum antibodies to induce ADE of RSV infection in vitro (119). Furthermore, ADE of infection has never been demonstrated in vivo. However, it must be noted that this has never been assessed during FI-RSV vaccineenhanced disease.

\section{ANTIBODY-DEPENDENT ENHANCEMENT (ADE) OF DISEASE}

ADE of disease, or instrinsic ADE (114), refers to a process in which the presence of pathogen-specific antibodies contributes to disease severity. For example, immune complexes might bind to Fc $\gamma$ R-expressing immune cells, modulating the immune response, and subsequently leading to enhanced inflammation. ADE of disease has been a presumed cause of severe disease following various viral infections and vaccinations (37, 114, 121-123). However, the underlying mechanisms are largely unknown and in vivo data supporting these claims are often lacking. However, for dengue virus infection some first clues to unravel the mechanism underlying $\mathrm{ADE}$ of disease have recently been published. Wang et al. have been able to show a correlation between Fc $\gamma$ RIIIA binding capacity of dengue virus antibodies and disease severity in vivo (21). The dengue-specific antibodies are thought to cross-react with platelet antigens and induce thrombocytopenia. Suggested underlying mechanisms are Fc $\gamma$ R-mediated platelet activation, phagocytosis, or ADCC, but further investigation is needed to confirm these hypotheses. In addition, Katzelnick et al. have shown that high denguespecific antibody titers correlate with protection, whereas intermediate antibody titers correlate with severe dengue disease (124). Although low or no antibody titers are not protective, they do not enhance disease. It is possible that RSV-specific antibodies show a similar pattern, as illustrated schematically in Figure 7.

\section{ADE of RSV Disease}

Although in vitro $\mathrm{ADE}$ of infection does not seem to be a determinant for severe RSV disease (119), other antibodymediated mechanisms could be involved, as has recently been shown for dengue virus infection (21). Many animal studies on RSV infection highlight the role of an excessive immune response in FI-RSV vaccine-enhanced disease. It is likely that poorly-neutralizing vaccine-induced antibodies play a role in the development of FI-RSV vaccine-enhanced disease (2224), although it remains uncertain which Fc-mediated effector functions are involved.

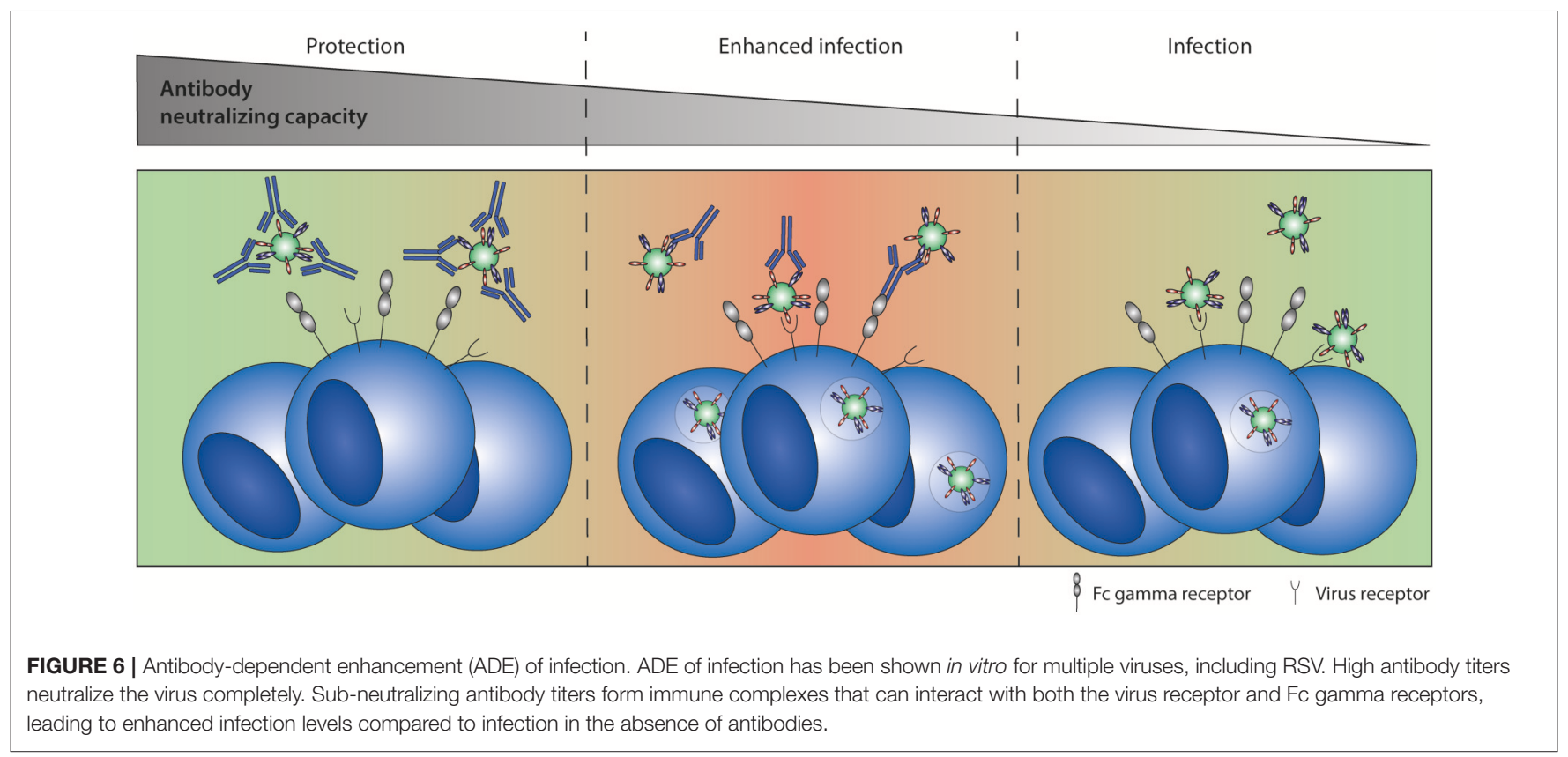




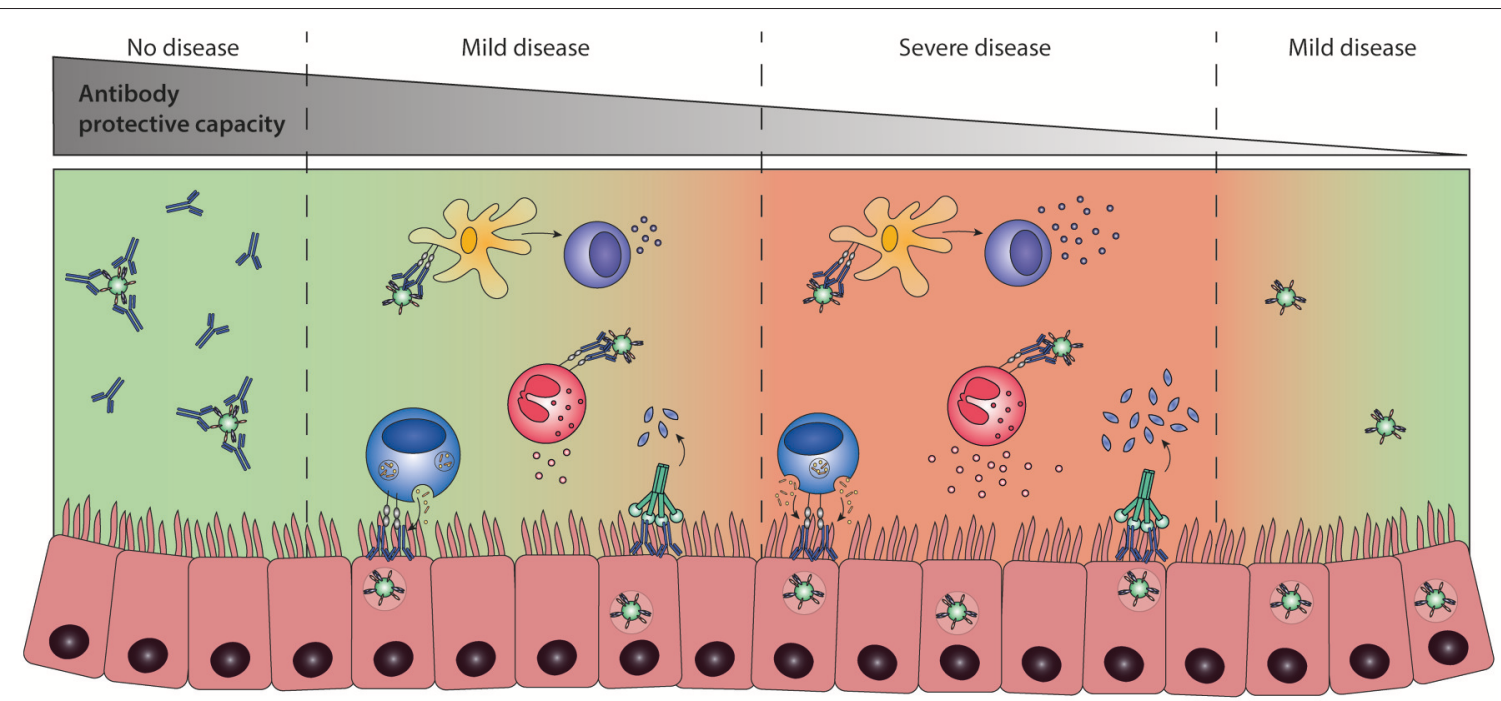

FIGURE 7 | Antibody-dependent enhancement (ADE) of disease. ADE of disease refers to a process in which the presence of pathogen-specific antibodies contributes to disease severity. Highly neutralizing antibodies result in sterile immunity, preventing infection and disease (left panel). The presence of low levels of protective antibodies allows for viral replication and leads to an Fc-mediated immune response that can either contribute to protection (second panel) or potentially lead to more severe disease (third panel) compared to infection in the absence of antibodies (right panel). It is currently unknown whether Fc-mediated effector functions can lead to severe disease and which immunological mechanisms determine the difference between protective or enhancing Fc-mediated responses.

Little is known on the involvement of (maternal) antibodies in the development of severe disease after natural RSV infection. Severe RSV infections are most frequently seen in the first 6 months of life when infants have circulating maternal RSV-specific antibodies (2). This suggests that RSV-specific antibodies may contribute to the induction of severe RSV disease. Results from animal studies with Fab fragments and Fc $\gamma \mathrm{R}$-knockout mice indeed show the involvement of antibody-mediated effector functions both in protection against viral replication $(58,60,61)$ and in promoting inflammation (92).

Some studies have reported enhanced RSV disease to occur in the presence of waning immunity. Murphy et al. reported enhanced pulmonary pathology 3 months after immunization with a RSV F glycoprotein vaccine (125), which was not seen 1 week after immunization (126). In a follow-up study, enhanced lung pathology was observed upon immunization with low doses of recombinant $\mathrm{F}$ protein, mimicking waning immunity (127). Interestingly, the enhanced disease was independent of the presence of a Th1- or Th2-biasing adjuvant.

Taken together, there are clear indications suggesting that Fc-mediated antibody effector functions may contribute to severe RSV disease. Complement activation has been linked to vaccine-enhanced disease and asthma, and may therefore also be involved in severe RSV disease upon natural infection. In addition, the immunomodulatory effects of immune complexes can lead to a pro-inflammatory environment, which is thought to be the underlying cause of RSV-mediated pathology. However, more research on the involvement of individual Fcmediated effector functions in disease outcome following RSV infection is needed.

\section{REGULATION OF FC-MEDIATED EFFECTOR FUNCTIONS}

Fc-mediated antibody effector functions play an important role in shaping the immune response and their active regulation is crucial to prevent excessive immune activation. A number of determinants have been found to influence Fc-mediated effector functions on both the cellular and antibody side of the $\mathrm{Fc}-\mathrm{Fc}$ receptor $(\mathrm{FcR})$ interaction. Important antibody characteristics are the isotype, subclass, glycosylation pattern, and antigen specificity, while important cellular determinants are the epitope position relative to the target cell membrane and $\mathrm{FcR}$ expression and polymorphisms on the effector cell, which together determine the capacity of the antibody to interact with specific FcRs. Most antibodies are not specifically eliciting a single effector function, and therefore the combination of all these characteristics determines the outcome of the various Fc-FcR interactions and the interaction with the complement system.

\section{ANTIBODY ISOTYPE AND SUBCLASS}

Antibodies consist of two functional domains: the variable antigen-binding fragment $(\mathrm{Fab})$ and the constant fragment $(\mathrm{Fc})$ that interacts with FcRs and C1q. The isotype of the Fc domain (IgA, IgD, IgE, IgG, and $\operatorname{IgM}$ ) represents the major determinant of Fc-mediated effector functions. Of these isotypes, IgG is the most important when it comes to Fc-mediated effector functions, as this is the only isotype known to interact with the widely expressed $\mathrm{Fc} \gamma \mathrm{Rs}$. Whereas, the majority of antibodies in serum are of the IgG subtype, IgA is the major isotype present in mucosal secretions. This isotype interacts with its specific 
receptor Fc $\alpha$ RI, which is present on neutrophils, eosinophils, monocytes, and macrophages [extensively reviewed in (128)]. Activation of FcaRI by IgA-opsonized pathogens can induce ADCC, phagocytosis, degranulation, and cytokine release. Other important isotypes to briefly mention are IgM, which is a potent complement activator (76), and IgE, which has been linked to various allergic diseases.

In humans, four different IgG subclasses (IgG1-IgG4) are known. These subclasses differ in amino acid sequence, which influences their capacity to interact with certain classes of Fc $\gamma$ Rs and complement components as depicted in Table 1. Production of different isotypes and subclasses is tightly regulated and dependent on differentiation of the $\mathrm{B}$ cell, which can be influenced by cytokines and interactions with patternrecognition receptors. The response to protein antigens usually involves $\mathrm{T}$ cell help and induces class switching to IgG1 or IgG3, whereas polysaccharide antigens induce class switching to IgG2 in the absence of $\mathrm{T}$ cell help (132). Viral infections, including RSV infections, mostly induce IgG1 and IgG3 antibody responses (133-135).

IgG1 and IgG3 have the highest affinity for FcyRs and are potent activators of complement, ADCC and phagocytosis (129, $136,137)$. IgG3 is the subclass with the highest potential to activate both Fc $\gamma$ Rs and complement, but due to its short half-life the preferred subclass for therapeutic cytotoxic activity is IgG1 (138). In contrast, receptor-blocking antibodies are often of the IgG2 or IgG4 subclass to avoid Fc-mediated cytotoxic side effects (139). Induction of specific subclasses can have major effects on the outcome of vaccine trials as has been shown for the HIV RV144 and VAX003 vaccines. RV144 recipients produced highly functional IgG3 antibodies that provided $31.2 \%$ efficacy, whereas VAX003 recipients elicited a monofunctional IgG4 antibody response that was not protective at all (140).

\section{Antibody Isotype and Subclass in RSV Infection}

Severe RSV-mediated disease is most prevalent in infants below 6 months of age. These children mainly rely on maternallyderived IgG for protection against infectious diseases, but the correlation between serum IgG levels and protection against RSV disease is poor $(7,9-11)$. A recent study by Habibi et al. found that mucosal IgA titers are a better predictor of susceptibility to RSV infection than serum IgG levels in an adult challenge model (141). In addition, they showed a hampered
IgA memory B cell response to RSV, which may explain the lifelong susceptibility to repeated RSV infections. In accordance with these results, lower levels of nasal IgA were found in naturally RSV-infected adults compared to healthy controls (142). These findings highlight the importance of mucosal IgA in protection against RSV infection. However, it is questionable whether IgA plays a role in protection or disease during primary infection. IgA antibodies to RSV are only found in secretions after 4 months of age, confirming they are synthesized as a result of (primary) infection (143). RSV-specific IgA has been shown to induce antibody-mediated effector functions. Although palivizumabIgA demonstrated slightly higher lysis of RSV-infected HEp2 cells by neutrophils (but not monocytes) in vitro, there was a somewhat decreased efficacy in vivo compared to palivizumabIgG (144). Additional experiments with Fc $\alpha$ RI transgenic mice suggest that IgA-mediated protection is Fc receptor-independent. No further research with RSV-IgA immune complexes has been published to date and therefore their role in protection or disease remains to be investigated.

Another interesting isotype is IgE, as the results from multiple studies suggest the involvement of this isotype in the development of RSV-mediated bronchiolitis and wheezing (145148). In a mouse model, RSV-specific IgE has been shown to enhance airway hyperresponsiveness (149). Since all infants produce IgE in response to RSV infection (150), it is thought that the height and duration of the IgE response are important for the induction of subsequent immunopathology $(148,151,152)$. Mast cells abundantly express the IgE-specific Fc receptor (FceRI) and were shown to play an important role in IgE-induced airway hyperresponsiveness in an RSV reinfection mouse model (149).

In addition to studies on isotypes, extensive studies have been performed on the presence of IgG subclasses during RSV infection. Wagner et al. have performed some early studies into the antibody subclass response to the RSV F and G glycoproteins in both infants and adults $(133,153,154)$. Primary RSV infections predominantly gave rise to IgG1 and IgG3 antibodies, whereas subsequent infection only led to an increase in IgG1 and IgG2 titers (133). RSV infection led to a poor IgG4 antibody response in all subjects. RSV F protein was the most immunogenic, leading to higher antibody titers compared to the RSV G protein (154). The IgG1/IgG2 ratio of antibody titers to the RSV F protein was fourfold higher than to the RSV G protein after the first three RSV infections in infants. This difference was thought to be due to the extensive glycosylation of the $G$

TABLE 1 | Binding capacity and functionality of lgG subclasses.

\begin{tabular}{|c|c|c|c|c|c|c|c|c|}
\hline Subclass & Serum abundance (\%) & Fc $\gamma R \mathbf{R I}$ & Fc $\gamma$ RIla & Fc $\gamma$ RIIb & Fc $\gamma$ RIIIa & Fc $\gamma$ RIIIb & C1q & Effector functions \\
\hline $\lg \mathrm{G} 1$ & 60 & +++ & +++ & + & ++ & +++ & ++ & ADCC, ADCP, CDC \\
\hline $\operatorname{lgG} 2$ & 32 & - & ++ & - & - & - & + & \\
\hline $\operatorname{lgG} 4$ & 4 & ++ & ++ & + & - & - & - & \\
\hline
\end{tabular}

(129-131). ADCC, antibody-dependent cell-mediated cytotoxicity; ADCP, antibody-dependent cellular phagocytosis; CDC, complement-dependent cytotoxicity; FC $\mathrm{R}$, FC gamma receptor; IgG, immunoglobulin $G$. 
protein, resulting in IgG2 antibodies. IgG1 and IgG3 are the most potent Fc $\gamma$ R-binding subclasses. This suggests that the majority of anti-RSV F antibodies are effective inducers of Fc-mediated effector functions, in contrast to the IgG2 subset of anti-RSV G antibodies. Experimental RSV infection in adults showed similar subclass responses to RSV F and G protein (153). A recent study confirms the findings of Wagner et al. showing a strong IgG3 response in infants younger than 4 months, despite the presence of high levels of maternal antibodies (155). A rise in RSV-specific IgG1 and IgG2 was only observed in infants older than 7 months.

Besides human studies, several mouse studies have been performed to investigate the subclass antibody response. Although some homology between mouse and human IgG subclasses has been found, it is unclear whether they induce the same downstream immune responses. In mice, neonatal IgG responses to RSV infection are significantly skewed toward mIgG1 (homologous to human IgG4), indicating a Th2 bias (156), whereas primary infection in adult mice leads to a balanced mIgG2a/mIgG1 response (homologous to human IgG1/IgG4) (157). Compared to wild-type RSV infection, immunization with inactivated or non-replicative RSV led to a low mIgG2a/mIgG1 ratio $(24,158)$. The largest proportion of antibodies directed at the RSV-F protein was mIgG2 (homologous to human IgG1), whereas the G protein response had a significantly lower proportion of mIgG2 (158). These results indicate that both the age of the host and the antigens determine the subclass response. However, it is remarkable that RSV infection leads to a poor IgG4 antibody response in humans, but to a high mIgG1 (homolog of human IgG4) response in (neonatal) mice. Thus, caution is warranted in the translation between human and mouse antibody studies.

Although extensive studies have been performed on the presence of specific subclasses, evidence on the role of these different subclasses during RSV infection is limited. One study describes a direct comparison between the functionality of palivizumab-IgG1 and -IgG2 (159). The neutralizing potential of both subclasses was comparable. However, the IgG2 antibody showed negligible binding to murine $\mathrm{Fc} \gamma \mathrm{Rs}$ and human $\mathrm{C} 1 \mathrm{q}$, resulting in less efficacy in vivo as measured by increased viral lung titers in challenged cotton rats (159). This finding underscores the protective potential of IgG1-mediated effector functions during RSV infection.

\section{ANTIBODY GLYCOSYLATION}

Glycosylation of the antibody Fc domain is another important regulator of Fc-mediated effector functions. Each IgG molecule contains a highly conserved asparagine at position 297 (N297) that functions as a glycosylation site that can harbor a variety of glycans, consisting of varying combinations of mannose, (bisecting) $\mathrm{N}$-acetylglycosamine (GlcNAc), fucose, galactose, and sialic acid (Figure 8). The complete absence of this glycan leads to a conformational state that is non-permissive for $\mathrm{Fc} \gamma \mathrm{R}$ or complement binding, thereby impairing Fc-mediated antibody effector functions.

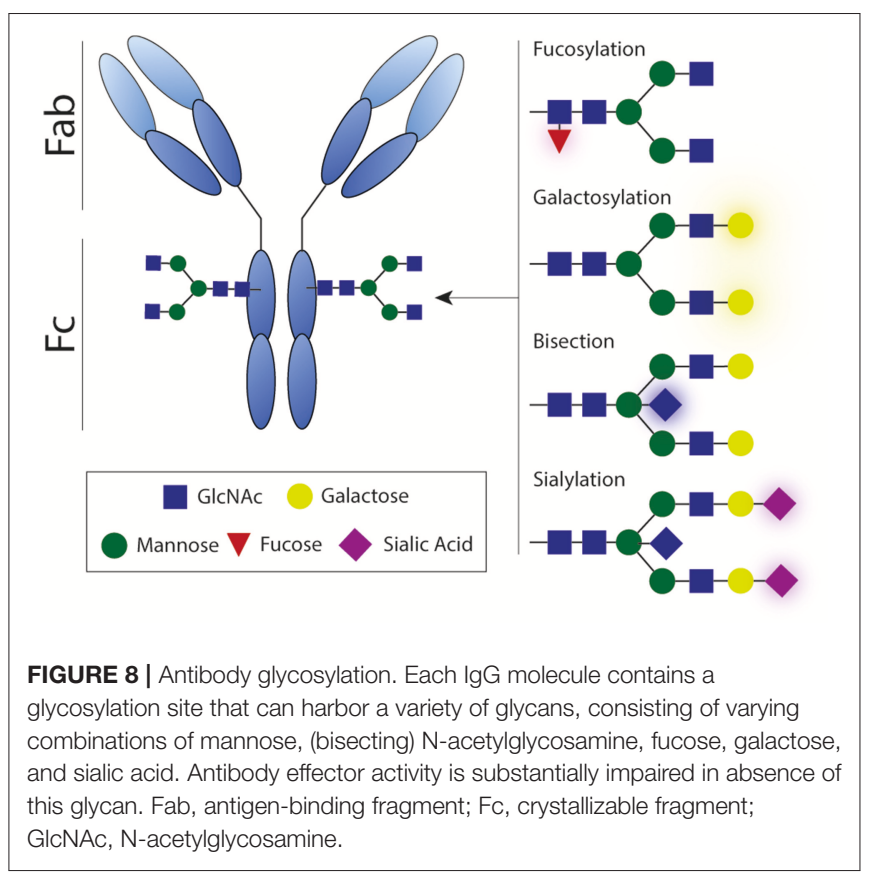

Afucosylation has the most straightforward influence on antibody effector functions. The absence of the core fucose on the Fc-glycan directly boosts ADCC activity by enhancing the interaction with Fc $\gamma$ RIIIA (Figure 2) (160-162). Interestingly, afucosylated mAbs have shown to be more protective against various infectious agents $(163,164)$ and more efficacious in cancer therapy $(165,166)$. However, increased levels of afucosylation are also associated with severe disease during secondary dengue infection (21).

Another biologically important modification to the Fc glycan is sialylation. The presence of sialic acid inhibits $F c \gamma R$ binding and is reported to be partly responsible for the anti-inflammatory activity of IVIg $(98,167)$. Besides having anti-inflammatory properties, sialylated Fc glycans have also been shown to induce the production of high-affinity broadly neutralizing antibodies against influenza virus (101).

Besides its effect on Fc receptor interactions, Fc glycosylation also affects complement $\mathrm{C} 1 \mathrm{q}$ binding to immune complexes. A recent study shows that elevated galactosylation and sialylation increase C1q-binding, downstream complement deposition, and complement dependent cytotoxicity (168). In contrast, agalactosylated IgG has also been suggested to elicit enhanced complement activation, considering its role in several autoimmune diseases (169). These findings suggest that activation of complement potentially contributes to pathogen clearance, but can also contribute to inflammation in autoimmune disease, highlighting the dual role of complement.

Fc glycosylation is subject to active regulatory mechanisms that control the composition of the glycan structure. Major changes in glycosylation occur during pregnancy $(170,171)$, upon vaccination $(101,172)$, and during certain viral infections (101). Therefore, insight in the glycosylation pattern during RSV infection and disease may provide valuable clues on the cause of severe RSV disease. 


\section{Antibody Glycosylation in RSV Infection}

To our knowledge, only one group has investigated the effect of glycosylation in the response toward RSV infection. Hiatt et al. compared the original Palivizumab mAb with an afucosylated and agalactosylated plant-produced glycovariant (G0) in different in vitro and in vivo assays (159). The G0 glycovariant showed enhanced binding to murine Fc $\gamma$ Rs but less binding to human $\mathrm{C} 1 \mathrm{q}$ compared to the parental Palivizumab, whereas neutralization capacity was comparable. The in vivo protective capacity of the G0 glycovariant was improved compared to the original, as evidenced by decreased pulmonary viral titers. In conclusion, this study suggests that the influence of Fc-glycosylation may be important in the protective capacity of RSV-specific antibodies but this needs to be studied in more detail for other mAbs and virus- and vaccine-induced antibodies.

\section{EPITOPE POSITION}

Next to antibody structure and glycosylation, the location of the antibody-bound epitope with respect to the membrane of the infected cell has been shown to be pivotal in determining Fc-mediated effector functions. Since the use of mAbs, it has been noticed that different mAbs binding the same target protein can elicit different effector mechanisms (173). Antibodies binding to epitopes closer to the membrane (membrane proximal epitopes) mediate ADCC and CDC activity more efficiently, whereas antibodies that target membrane distal epitopes are often highly neutralizing and efficient ADCP-inducers (13, 174-176). More specifically, recent research suggests that ADCP is most efficiently triggered when antibodies bind within $10 \mathrm{~nm}$ from the cell surface (177), indicating that the optimal ADCP-inducing epitope is located neither too close, nor too far away from the cell membrane. These studies suggest that besides the common need for particular Fc-Fc $\gamma \mathrm{R}$ interactions, there are fundamental differences in the activation requirements of specific Fc-mediated effector functions. For CDC activity, stabilization of complement components on the cell surface is essential. This would require a short distance from epitope to cell membrane. During ADCC, the formation of an immune synapse is essential. This small synapse can only be formed when the NK cells engage antibodies bound in close proximity to the cell membrane, explaining the need for membrane proximal epitopes (175).

\section{Important Epitopes in RSV Infection}

Neutralization of RSV is mainly established by antibodies against the RSV F and RSV G protein (178). Antibodies against the $\mathrm{SH}$ and $\mathrm{N}$ protein have also been described $(179,180)$ and although these antibodies are not involved in neutralization, they may have other important (Fc-mediated) functions (181). Capella et al. recently showed that antibodies against the pre-F protein were the most prevalent RSV-specific serum antibodies in infants below 2 years of age (182). Both serum IgG levels against anti-RSV pre-F and G correlated with disease severity in this study.

Various antigenic sites (named $\varnothing$ and I-VIII) have been described for the two conformational states of the RSV F protein $(183,184)$. Pre-F-specific antibodies are better neutralizers than
post-F-specific antibodies (185). However, not all pre-fusion $\mathrm{F}$ antibodies have similar neutralizing activity (183). The most potent neutralizing antibodies bind to distal epitopes, suggesting that the neutralizing potential of anti-RSV F antibodies not only relies on the conformation of $\mathrm{F}$ on which the epitope is present (e.g., pre- vs. post-F), but may also depend on the location of the epitope relative to the viral or cellular membrane. As described above, the proximity to the membrane determines the efficiency of Fc-mediated effector functions $(13,174,175)$. This suggests that potently-neutralizing antibodies, binding to distal epitopes, may also be efficient inducers of ADCP. Antibodies binding to proximal epitopes are generally less neutralizing, but may be more potent in inducing ADCC and CDC.

The most important antigenic site for the RSV G protein is the central conserved domain (CCD). Despite the high variability of RSV G, antibodies against the CCD are broadly neutralizing against both RSV A and B strains (186). The $\mathrm{G}$ protein $\mathrm{CCD}$ binds to the CX3CR1 receptor, leading to attachment of RSV to its target cells (187). Antibodies against this receptor-binding domain efficiently neutralize RSV infection and decrease pathogenesis by binding soluble $G$ protein, an immune evasion protein secreted by RSV-infected cells (56, 57, 188). Soluble $\mathrm{G}$ protein has been found to inhibit Fc-mediated antiviral effects of macrophages and complement (75), and to modulate trafficking of CX3CR1 $(+)$ cells (189). Next to the important roles mentioned above, antibodies against the CCD domain are also able to induce Fc-mediated effector functions like ADCP and ADCC (56).

Taken together, not only the antigen but also the epitope determines the efficacy of antibodies. Interestingly, evidence suggests that targeted epitopes may differ between infants and adults (190), but the effect of these changes on the efficacy of the antibody response is unknown. Further research may uncover the relation between antigenic site and effector functions against RSV infection, and thereby reveal preferred antibody-binding sites for protection against RSV disease.

\section{FC $\gamma$ R EXPRESSION AND POLYMORPHISMS}

Another regulator of Fc-mediated effector functions is the expression pattern and polymorphisms of Fc $\gamma$ Rs. The majority of leukocytes express more than one $\mathrm{Fc} \gamma \mathrm{R}$ type with varying downstream signaling activities. The level and variety of Fc $\gamma \mathrm{R}$ expression is tightly regulated during leukocyte development and can be modulated by certain mediators present during infection, inflammation, or even vaccination (103, 191). As stated before, the balance between inhibitory and activating Fc $\gamma \mathrm{R}$ interactions is crucial in regulating B cell IgG responses (99-101) and skewing APC maturation and antigen presentation (102105). Additionally, co-engagement and signaling through other receptors such as TLRs may influence the activation threshold (192). Altogether, this points out the importance of receptor expression patterns on effector cells.

Besides variation in $\mathrm{Fc} \gamma \mathrm{R}$ expression patterns, single nucleotide polymorphisms (SNPs) in FcyRs occur. Although 
many SNPs have been identified, only few have been shown to impact receptor function (193). One of the functional SNPs has been identified in Fc $\gamma$ RIIa. Only the R131H allelic variant of this receptor is capable of interacting with IgG2, enabling efficient phagocytosis $(194,195)$. Another SNP affecting binding affinity has been characterized for Fc $\gamma$ RIII, which has two co-dominantly expressed allotypes: V158 and F158. The presence of a valine residue at position 158 increases the affinity for IgG1 and IgG3, augmenting for example NK cell activity $(196,197)$.

\section{Fc $\gamma R$ Expression and Polymorphisms in RSV Infection}

Different Fc $\gamma$ Rs can have opposing effects on the immune response, as has also been shown for RSV. In $\mathrm{Fc}_{\mathrm{r}} \mathrm{R}^{-/-}$ mouse models, Gomez et al. demonstrate that murine Fc $\gamma$ RIII (homolog of human Fc $\gamma$ RIIA) contributes to viral replication and airway inflammation, whereas murine Fc $\gamma$ RIIb (homolog of human Fc $\gamma \mathrm{RIIb}$ ) has a protective effect as was shown by a decrease in viral titers (110). In vitro, RSV infection has been found to increase $\mathrm{mFc} \gamma \mathrm{RII}$ and $\mathrm{mFc} \gamma \mathrm{RIII}$ expression in murine macrophage cultures which subsequently showed enhanced phagocytosis (198).

Although the clinical relevance of Fc $\gamma \mathrm{R}$ SNPs has been studied intensively for auto-immune diseases (199), cancer treatment (200) and various viral infections (201-204), there is no data on the role of these polymorphisms in RSV infection or disease. In a genetic association study, performed to identify genes that are involved in RSV susceptibility, a SNP in FCER1A was found (205). This polymorphism had previously been found to be associated with altered FceRI expression levels and allergic disease, supporting the involvement of IgE in RSVmediated disease.

\section{IMPLICATIONS FOR VACCINE AND mAb DEVELOPMENT}

Currently there are no market-approved vaccines or antivirals available against RSV. The only available treatment is the administration of a prophylactic $F$ protein-specific $\mathrm{mAb}$ (Palivizumab) to reduce hospitalization in high-risk infants (206). However, the use of Palivizumab is restricted and its cost-effectiveness is often discussed (207). Improved mAbs with higher efficacy rates are thus highly needed and many research efforts are ongoing to develop these mAbs. A recent clinical trial with a pre-F-specific mAb (Suptavamab) failed to demonstrate efficacy in pre-term infants although the $\mathrm{mAb}$ was superior to Palivizumab in neutralization tests in vitro and in reducing viral load in the cotton rat model (208) (press release Regeneron, August 14, 2017). The failure of this highly neutralizing $\mathrm{mAb}$ indicates that protection against RSV-mediated disease, which is known to be immunopathological in nature, depends on more than just neutralization of the virus.

In addition to efforts made to develop improved therapeutic $\mathrm{mAbs}$, there is an extensive pipeline of vaccines that are currently being tested in different phases of clinical development (https:// www.path.org/resources/rsv-vaccine-and-mab-snapshot/). The development of vaccines is of great importance, especially for developing countries where RSV-related mortality is high and $\mathrm{mAb}$ therapy is inaccessible due to high costs. The majority of vaccine candidates currently in clinical trials are designed to induce systemic IgG, mostly against the RSV F protein. The results of the pre-F-specific Suptuvamab and the recent failures of two F-specific vaccine candidates tested in elderly, imply that a broader and more polyfunctional immune response may be needed to confer protection against RSV-mediated disease $(209,210)$ (press release Novavax, September 15, 2016).

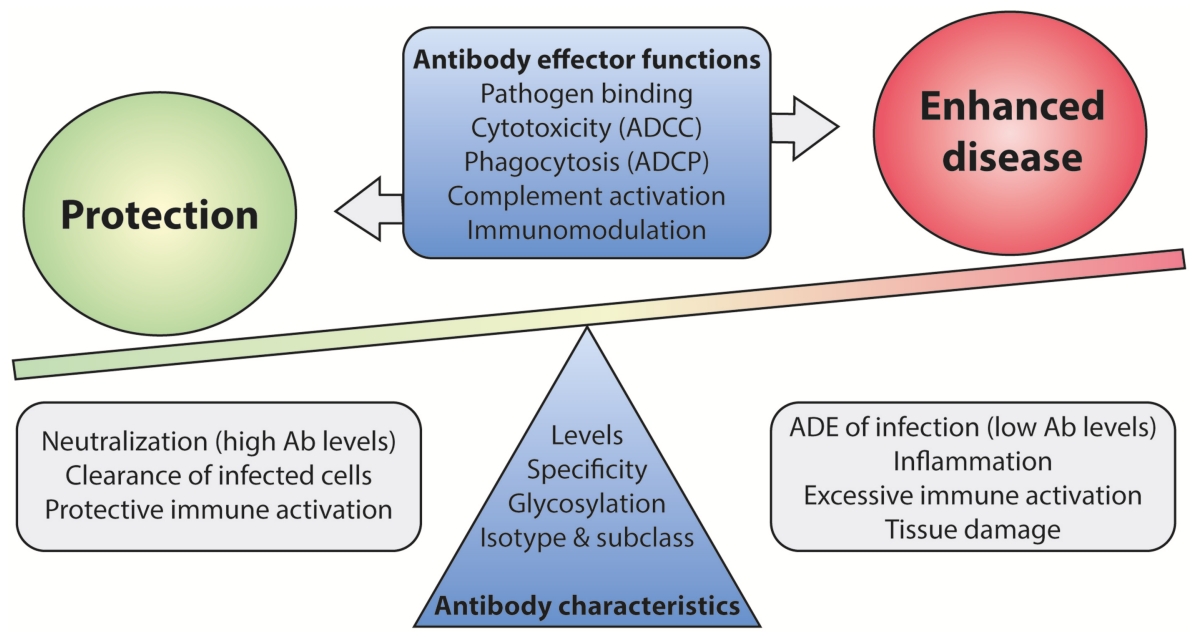

FIGURE 9 | The balance between Fc-mediated protection and enhanced disease. Antibody effector functions, regulated by differences in antibody characteristics, are suspected to play a role in disease outcome upon RSV infection. Immune activation by Fc-mediated effector functions is likely needed for efficient viral clearance. However, excessive activation may lead to inflammation and tissue damage. A balanced and contained immune response is most likely the key to protection upon infection. Ab, antibody; ADCC, antibody-dependent cell-mediated cytotoxicity; ADCP, antibody-dependent cellular phagocytosis; ADE, antibody-dependent enhancement. 
To this date, no accurate correlate of protection has been defined for RSV infection as virus-specific antibody levels or neutralization titers do not seem of use in this respect. The lack of a well-defined correlate of protection complicates the development of new vaccines, as efficacy now has to be demonstrated in expensive large-scale clinical trials. Mounting evidence suggests that antibody effector functions beyond neutralization can contribute to both protection and disease (110, 159, 181, 211). A balanced activation of different Fc-mediated effector functions is key to prevent excessive inflammation and tissue damage (Figure 9). It will be of importance to implement assays that identify Fc-mediated effector functions of mAbs and vaccine-induced antibodies. Studies in Fc $\gamma \mathrm{R}$-knockout mice have indicated the importance of $\mathrm{Fc}-\mathrm{Fc} \gamma \mathrm{R}$ interactions for protection against RSV infection $(110,181)$, but the testing of mAbs and vaccines demands high-throughput approaches. Systems serology captures a wide array of antibody characteristics and effector functions. It has proven effective in identifying antibody features that contribute to protection for various (viral) pathogens $(19,212,213)$. Such an approach will provide detailed information on the characteristics that are required for a protective RSV antibody response.

The ability to generate an antibody profile that selectively binds particular epitopes and Fc $\gamma$ Rs is important to enable the induction of only the desired antibody effector functions. Recent developments now allow targeted modifications to mAbs that can lead to enhancement or inhibition of specific Fc-mediated antibody effector functions through glyco-engineering or the induction of specific antibody subclasses or isotypes (159). In the future, this might also be possible for vaccines.

One can conclude from the studies presented above that Fc-FcR interactions are an integral component of the immune response against RSV and should be considered in the rational design of next generation RSV-specific mAbs and vaccines. Only limited data is available on the effect of specific Fcmediated antibody effector functions during RSV infection, but it is clear that these can be both beneficial and detrimental for protection against RSV infection and disease outcome. In the future, Fc-mediated effector functions might be harnessed to optimize the efficacy of RSV-specific mAbs and vaccineinduced antibodies. However, our current knowledge on the precise role of individual effector functions in RSV disease is too limited to rationally design such antibodies and vaccines. Therefore, until the individual contributions of Fc-mediated effector functions to protection and disease are unraveled, aiming to induce highly neutralizing antibodies seems the safest approach. These antibodies will need to halt the infection at the site of entry and thereby prevent excessive (antibody-mediated) immune activation. It remains to be seen whether complete neutralization can be achieved via the induction of serum IgG alone, or whether the induction of mucosal IgA is necessary for reliable neutralization activity. The many clinical trials that are currently ongoing with maternal and neonatal vaccine candidates will show whether these approaches indeed result in protection during the first, most vulnerable, months of life.

\section{CONCLUDING REMARKS}

Neutralizing antibody titers do not adequately correlate with protection against RSV disease. Interestingly, antibodies have additional Fc-mediated effector functions besides neutralization, but this area of research is currently underappreciated in the RSV field. With this review, we aim to encourage a paradigm shift from neutralization-based studies toward functional studies examining the precise role of Fc-mediated antibody effector functions in vaccine efficacy and RSV disease. We have evaluated the current literature on the effect of RSV-specific antibodies on NK cells, phagocytes, the complement system, cytokine production, and B- and T-cell skewing. Multiple in vivo studies using Fc $\gamma \mathrm{R}$-knockout mice or modified RSVspecific antibodies indicate the importance of Fc-mediated effector functions in protection from RSV infection and disease $(110,159,181,211)$. In addition, Fc-mediated effector functions might have a role in ADE of RSV disease (22, 23). However, most studies into vaccine and mAb efficacy still only report antibody (neutralization) titers and disregard any Fc-mediated effector functions. The importance of these antibody effector functions has already been shown for multiple clinically important viral pathogens and is only starting to be explored for RSV. In our view, a better understanding of the broad range of effector mechanisms that are induced by RSVspecific antibodies will greatly contribute to the much-needed development and testing of next generation mAbs and vaccines against this virus.

\section{AUTHOR CONTRIBUTIONS}

EvE, WL, and PvK conceived the topic and scope of this review. $\mathrm{EvE}$ researched the literature and designed the figures. EvE and PvK drafted the first version of the manuscript. WL and GF critically reviewed the manuscript. All authors approved the final manuscript.

\section{FUNDING}

This work was supported by the Dutch Ministry of Health, Welfare and Sport (Strategic Program RIVM S/112008), the Virgo consortium (FES0908), and the Netherlands Genomics Initiative (050-060-452).

\section{ACKNOWLEDGMENTS}

We want to thank Dr. Elise Hovingh for support on the design of the figures and Dr. Diana Wouters for helpful comments. 


\section{REFERENCES}

1. Shi T, McAllister DA, O’Brien KL, Simoes, EAF, Madhi SA, Gessner BD, et al. Global, regional, and national disease burden estimates of acute lower respiratory infections due to respiratory syncytial virus in young children in 2015: a systematic review and modelling study. Lancet. (2017) 390:946-58. doi: 10.1016/S0140-6736(17)30938-8

2. Hall CB, Weinberg GA, Iwane MK, Blumkin AK, Edwards KM, Staat MA, et al. The burden of respiratory syncytial virus infection in young children. N Engl J Med. (2009) 360:588-98. doi: 10.1056/NEJMoa0804877

3. Geoghegan S, Erviti A, Caballero MT, Vallone F, Zanone SM, Losada JV, et al. Mortality due to respiratory syncytial virus. Burden and Risk Factors. Am J Respir Crit Care Med. (2017) 195:96-103. doi: 10.1164/rccm.201603-0658OC

4. Glezen WP, Taber LH, Frank AL, Kasel JA. Risk of primary infection and reinfection with respiratory syncytial virus. Am J Dis Child. (1986) 140:5436. doi: 10.1001/archpedi.1986.02140200053026

5. Eick A, Karron R, Shaw J, Thumar B, Reid R, Santosham M, et al. The role of neutralizing antibodies in protection of American Indian infants against respiratory syncytial virus disease. Pediatr Infect Dis J. (2008) 27:207-12. doi: 10.1097/INF.0b013e31815ac585

6. Chu HY, Steinhoff MC, Magaret A, Zaman K, Roy E, Langdon G, et al. Respiratory syncytial virus transplacental antibody transfer and kinetics in mother-infant pairs in Bangladesh. J Infect Dis. (2014) 210:1582-9. doi: 10.1093/infdis/jiu316

7. Vieira SE, Gilio AE, Durigon EL, Ejzenberg B. Lower respiratory tract infection caused by respiratory syncytial virus in infants: the role played by specific antibodies. Clinics. (2007) 62:709-16. doi: 10.1590/S1807-59322007000600009

8. Stensballe LG, Ravn H, Kristensen K, Agerskov K, Meakins T, Aaby P, et al. Respiratory syncytial virus neutralizing antibodies in cord blood, respiratory syncytial virus hospitalization, and recurrent wheeze. J Allergy Clin Immunol. (2009) 123:398-403. doi: 10.1016/j.jaci.2008.10.043

9. Nyiro JU, Sande CJ, Mutunga M, Kiyuka PK, Munywoki PK, Scott JA, et al. Absence of association between cord specific antibody levels and severe Respiratory Syncytial Virus (RSV) disease in early infants: a case control study from Coastal Kenya. PLoS ONE. (2016) 11:e0166706. doi: 10.1371/journal.pone.0166706

10. Chu HY, Tielsch J, Katz J, Magaret AS, Khatry S, LeClerq SC, et al. Transplacental transfer of maternal respiratory syncytial virus (RSV) antibody and protection against RSV disease in infants in rural Nepal. J Clin Virol. (2017) 95:90-5. doi: 10.1016/j.jcv.2017.08.017

11. Jans J, Wicht O, Widjaja I, Ahout IM, de Groot R, Guichelaar T, et al. Characteristics of RSV-specific maternal antibodies in plasma of hospitalized, acute RSV patients under three months of age. PLoS ONE. (2017) 12:e0170877. doi: 10.1371/journal.pone.0170877

12. Plotkin SA, Gilbert P. (2018). Correlates of protection. In: Plotkin SA, editor. Plotkin's Vaccines. 7th ed. Philadelphia, PA: Elsevier. 35-40. doi: 10.1016/B978-0-323-35761-6.00003-1

13. DiLillo DJ, Tan GS, Palese P, Ravetch JV. Broadly neutralizing hemagglutinin stalk-specific antibodies require $\mathrm{F}_{\mathrm{c}} \mathrm{R}$ interactions for protection against influenza virus in vivo. Nat Med. (2014) 20:143-51. doi: 10.1038/nm.3443

14. Henry Dunand CJ, Leon PE, Huang M, Choi A, Chromikova V, Ho IY, et al. Both neutralizing and non-neutralizing human H7N9 influenza vaccineinduced monoclonal antibodies confer protection. Cell Host Microbe. (2016) 19:800-13. doi: 10.1016/j.chom.2016.05.014

15. Vanderven HA, Liu L, Ana-Sosa-Batiz F, Nguyen TH, Wan Y, Wines B, et al. Fc functional antibodies in humans with severe H7N9 and seasonal influenza. JCI Insight. (2017) 2:92750. doi: 10.1172/jci.insight.92750

16. Hessell AJ, Hangartner L, Hunter M, Havenith CE, Beurskens FJ, Bakker $\mathrm{JM}$, et al. Fc receptor but not complement binding is important in antibody protection against HIV. Nature. (2007) 449:101-4. doi: 10.1038/nature06106

17. Bournazos S, Klein F, Pietzsch J, Seaman MS, Nussenzweig MC, Ravetch JV. Broadly neutralizing anti-HIV-1 antibodies require Fc effector functions for in vivo activity. Cell. (2014) 158:1243-53. doi: 10.1016/j.cell.2014.08.023

18. Gunn BM, Yu WH, Karim MM, Brannan JM, Herbert AS, Wec AZ, et al. A role for $\mathrm{Fc}$ function in therapeutic monoclonal antibody-mediated protection against ebola virus. Cell Host Microbe. (2018) 24:221-233.e225. doi: 10.1016/j.chom.2018.07.009
19. Saphire EO, Schendel SL, Fusco ML, Gangavarapu K, Gunn BM, Wec AZ, et al. Systematic analysis of monoclonal antibodies against ebola virus GP defines features that contribute to protection. Cell. (2018) 174:938-52 e913. doi: 10.1016/j.cell.2018.07.033

20. Acosta EG, Bartenschlager R. Paradoxical role of antibodies in dengue virus infections: considerations for prophylactic vaccine development. Expert Rev Vacc. (2016) 15:467-82. doi: 10.1586/14760584.2016.1121814

21. Wang TT, Sewatanon J, Memoli MJ, Wrammert J, Bournazos S, Bhaumik SK, et al. IgG antibodies to dengue enhanced for Fc $\gamma$ RIIIA binding determine disease severity. Science. (2017) 355:395-8. doi: 10.1126/science.aai8128

22. Polack FP, Teng MN, Collins PL, Prince GA, Exner M, Regele H, et al. A role for immune complexes in enhanced respiratory syncytial virus disease. J Exp Med. (2002) 196:859-65. doi: 10.1084/jem.20020781

23. Openshaw PJ, Tregoning JS. Immune responses and disease enhancement during respiratory syncytial virus infection. Clin Microbiol Rev. (2005) 18:541-55. doi: 10.1128/CMR.18.3.541-555.2005

24. Delgado MF, Coviello S, Monsalvo AC, Melendi GA, Hernandez JZ, Batalle JP, et al. Lack of antibody affinity maturation due to poor Toll-like receptor stimulation leads to enhanced respiratory syncytial virus disease. Nat Med. (2009) 15:34-41. doi: 10.1038/nm.1894

25. Smyth MJ, Cretney E, Kelly JM, Westwood JA, Street SE, Yagita H, et al. Activation of NK cell cytotoxicity. Mol Immunol. (2005) 42:501-10. doi: 10.1016/j.molimm.2004.07.034

26. Scott AM, Wolchok JD, Old LJ. Antibody therapy of cancer. Nat Rev Cancer. (2012) 12:278-87. doi: 10.1038/nrc3236

27. Bonsignori M, Pollara J, Moody MA, Alpert MD, Chen X, Hwang KK, et al. Antibody-dependent cellular cytotoxicity-mediating antibodies from an HIV-1 vaccine efficacy trial target multiple epitopes and preferentially use the VH1 gene family. J Virol. (2012) 86:11521-32. doi: 10.1128/JVI.01023-12

28. Haynes BF, Gilbert PB, McElrath MJ, Zolla-Pazner S, Tomaras GD, Alam SM, et al. Immune-correlates analysis of an HIV-1 vaccine efficacy trial. $N$ Engl J Med. (2012) 366:1275-86. doi: 10.1056/NEJMoa1113425

29. Corey L, Gilbert PB, Tomaras GD, Haynes BF, Pantaleo G, Fauci AS. Immune correlates of vaccine protection against HIV-1 acquisition. Sci Transl Med. (2015) 7:310rv317. doi: 10.1126/scitranslmed.aac7732

30. Baum LL, Cassutt KJ, Knigge K, Khattri R, Margolick J, Rinaldo C, et al. HIV1 gp120-specific antibody-dependent cell-mediated cytotoxicity correlates with rate of disease progression. J Immunol. (1996) 157:2168-73.

31. Lambotte O, Ferrari G, Moog C, Yates NL, Liao HX, Parks RJ, et al. Heterogeneous neutralizing antibody and antibody-dependent cell cytotoxicity responses in HIV-1 elite controllers. AIDS. (2009) 23:897-906. doi: 10.1097/QAD.0b013e328329f97d

32. Wren LH, Chung AW, Isitman G, Kelleher AD, Parsons MS, Amin J, et al. Specific antibody-dependent cellular cytotoxicity responses associated with slow progression of HIV infection. Immunology. (2013) 138:116-23. doi: 10.1111/imm.12016

33. Ackerman ME, Mikhailova A, Brown EP, Dowell KG, Walker BD, Bailey-Kellogg C, et al. Polyfunctional HIV-Specific Antibody Responses Are Associated with Spontaneous HIV Control. PLoS Pathog. (2016) 12:e1005315. doi: 10.1371/journal.ppat.1005315

34. Jegaskanda S, Luke C, Hickman HD, Sangster MY, Wieland-Alter WF, McBride JM, et al. Generation and protective ability of influenza virusspecific antibody-dependent cellular cytotoxicity in humans elicited by vaccination, natural infection, and experimental challenge. J Infect Dis. (2016) 214:945-52. doi: 10.1093/infdis/jiw262

35. Vanderven HA, Jegaskanda S, Wheatley AK, Kent SJ. Antibody-dependent cellular cytotoxicity and influenza virus. Curr Opin Virol. (2017) 22:89-96. doi: 10.1016/j.coviro.2016.12.002

36. Huber VC, Lynch JM, Bucher DJ, Le J, Metzger DW. Fc receptormediated phagocytosis makes a significant contribution to clearance of influenza virus infections. J Immunol. (2001) 166:7381-8. doi: 10.4049/jimmunol.166.12.7381

37. Khurana S, Loving CL, Manischewitz J, King LR, Gauger PC, Henningson $\mathrm{J}$, et al. Vaccine-induced anti-HA2 antibodies promote virus fusion and enhance influenza virus respiratory disease. Sci Transl Med. (2013) 5:200ra114. doi: 10.1126/scitranslmed.3006366

38. Co MD, Terajima M, Thomas SJ, Jarman RG, Rungrojcharoenkit K, Fernandez $S$, et al. Relationship of preexisting influenza hemagglutination 
inhibition, complement-dependent lytic, and antibody-dependent cellular cytotoxicity antibodies to the development of clinical illness in a prospective study of A(H1N1)pdm09 Influenza in children. Viral Immunol. (2014) 27:375-82. doi: 10.1089/vim.2014.0061

39. Ye ZW, Yuan S, Poon KM, Wen L, Yang D, Sun Z, et al. Antibody-dependent cell-mediated cytotoxicity epitopes on the hemagglutinin head region of pandemic H1N1 influenza virus play detrimental roles in H1N1-infected mice. Front Immunol. (2017) 8:317. doi: 10.3389/fimmu.2017.00317

40. Garcia G, Arango M, Perez AB, Fonte L, Sierra B, Rodriguez-Roche R, et al. Antibodies from patients with dengue viral infection mediate cellular cytotoxicity. J Clin Virol. (2006) 37:53-7. doi: 10.1016/j.jcv.2006.04.010

41. Laoprasopwattana K, Libraty DH, Endy TP, Nisalak A, Chunsuttiwat S, Ennis FA, et al. Antibody-dependent cellular cytotoxicity mediated by plasma obtained before secondary dengue virus infections: potential involvement in early control of viral replication. J Infect Dis. (2007) 195:1108-16. doi: $10.1086 / 512860$

42. Liu Q, Fan C, Li Q, Zhou S, Huang W, Wang L, et al. Antibodydependent-cellular-cytotoxicity-inducing antibodies significantly affect the post-exposure treatment of Ebola virus infection. Sci Rep. (2017) 7:45552. doi: $10.1038 /$ srep 45552

43. Hussell T, Openshaw PJ. Intracellular IFN-gamma expression in natural killer cells precedes lung CD8+ $\mathrm{T}$ cell recruitment during respiratory syncytial virus infection. J Gen Virol. (1998) 79(Pt 11):2593-601. doi: 10.1099/0022-1317-79-11-2593

44. Li F, Zhu H, Sun R, Wei H, Tian Z. Natural killer cells are involved in acute lung immune injury caused by respiratory syncytial virus infection. J Virol. (2012) 86:2251-8. doi: 10.1128/JVI.06209-11

45. Long X, Xie J, Zhao K, Li W, Tang W, Chen S, et al. NK cells contribute to persistent airway inflammation and AHR during the later stage of RSV infection in mice. Med Microbiol Immunol. (2016) 205:459-70. doi: 10.1007/s00430-016-0459-9

46. Welliver TP, Garofalo RP, Hosakote Y, Hintz KH, Avendano L, Sanchez K, et al. Severe human lower respiratory tract illness caused by respiratory syncytial virus and influenza virus is characterized by the absence of pulmonary cytotoxic lymphocyte responses. J Infect Dis. (2007) 195:1126-36. doi: $10.1086 / 512615$

47. Larranaga CL, Ampuero SL, Luchsinger VF, Carrion FA, Aguilar NV, Morales $\mathrm{PR}$, et al. Impaired immune response in severe human lower tract respiratory infection by respiratory syncytial virus. Pediatr Infect Dis J. (2009) 28:867-73. doi: 10.1097/INF.0b013e3181a3ea71

48. Brand HK, Ferwerda G, Preijers F, de Groot R, Neeleman C, Staal FJ, et al. CD4+ T-cell counts and interleukin-8 and CCL-5 plasma concentrations discriminate disease severity in children with RSV infection. Pediatr Res. (2013) 73:187-93. doi: 10.1038/pr.2012.163

49. Leahy TR, McManus R, Doherty DG, Grealy R, Coulter T, Smyth P, et al. Interleukin-15 is associated with disease severity in viral bronchiolitis. Eur Respir J. (2016) 47:212-22. doi: 10.1183/13993003.00642-2015

50. Tripp RA, Moore D, Barskey A IV, Jones L, Moscatiello C, Keyserling H, et al. Peripheral blood mononuclear cells from infants hospitalized because of respiratory syncytial virus infection express $\mathrm{T}$ helper-1 and T helper-2 cytokines and CC chemokine messenger RNA. J Infect Dis. (2002) 185:138894. doi: 10.1086/340505

51. Kerrin A, Fitch P, Errington C, Kerr D, Waxman L, Riding K, et al. Differential lower airway dendritic cell patterns may reveal distinct endotypes of RSV bronchiolitis. Thorax. (2017) 72:620-7. doi: 10.1136/thoraxjnl-2015-207358

52. Scott R, de Landazuri MO, Gardner PS, Owen JJ. Human antibodydependent cell-mediated cytotoxicity against target cells infected with respiratory syncytial virus. Clin Exp Immunol. (1977) 28:19-26.

53. Meguro H, Kervina M, Wright PF. Antibody-dependent cell-mediated cytotoxicity against cells infected with respiratory syncytial virus: characterization of in vitro and in vivo properties. I Immunol. (1979) 122:2521-6.

54. McLellan JS, Chen M, Leung S, Graepel KW, Du X, Yang Y, et al. Structure of RSV fusion glycoprotein trimer bound to a prefusion-specific neutralizing antibody. Science. (2013) 340:1113-7. doi: 10.1126/science.1234914

55. Gupta N, LeGoff J, Chamat S, Mercier-Delarue S, Touzelet O, Power UF, et al. Affinity-purified respiratory syncytial virus antibodies from intravenous immunoglobulin exert potent antibody-dependent cellular cytotoxicity. PLoS ONE. (2013) 8:e69390. doi: 10.1371/journal.pone.0069390

56. Cortjens B, Yasuda E, Yu X, Wagner K, Claassen YB, Bakker AQ, et al. ls. J Virol. (2017) 91:e02357-16. doi: 10.1128/JVI.02357-16

57. Haynes LM, Caidi H, Radu GU, Miao C, Harcourt JL, Tripp RA, et al. Therapeutic monoclonal antibody treatment targeting respiratory syncytial virus (RSV) G protein mediates viral clearance and reduces the pathogenesis of RSV infection in BALB/c mice. J Infect Dis. (2009) 200:439-47. doi: $10.1086 / 600108$

58. Miao C, Radu GU, Caidi H, Tripp RA, Anderson LJ, Haynes LM. Treatment with respiratory syncytial virus $G$ glycoprotein monoclonal antibody or $\mathrm{F}\left(\mathrm{ab}^{\prime}\right) 2$ components mediates reduced pulmonary inflammation in mice. J Gen Virol. (2009) 90(Pt 5):1119-23. doi: 10.1099/vir.0.009 308-0

59. Kaul TN, Welliver RC, Ogra PL. Development of antibody-dependent cellmediated cytotoxicity in the respiratory tract after natural infection with respiratory syncytial virus. Infect Immun. (1982) 37:492-8.

60. Corbeil S, Seguin C, Trudel M. Involvement of the complement system in the protection of mice from challenge with respiratory syncytial virus Long strain following passive immunization with monoclonal antibody 18A2B2. Vaccine. (1996) 14:521-5. doi: 10.1016/0264-410X(95)00222-M

61. Mekseepralard C, Toms GL, Routledge EG. Protection of mice against Human respiratory syncytial virus by wild-type and aglycosyl mouse-human chimaeric IgG antibodies to subgroup-conserved epitopes on the G glycoprotein. J Gen Virol. (2006) 87(Pt 5):1267-73. doi: 10.1099/vir.0.81660-0

62. He W, Chen CJ, Mullarkey CE, Hamilton JR, Wong CK, Leon PE, et al. Alveolar macrophages are critical for broadly-reactive antibody-mediated protection against influenza A virus in mice. Nat Commun. (2017) 8:846. doi: 10.1038/s41467-017-00928-3

63. Ana-Sosa-Batiz F, Vanderven H, Jegaskanda S, Johnston A, Rockman S, Laurie $\mathrm{K}$, et al. Influenza-specific antibody-dependent phagocytosis. PLoS ONE. (2016) 11:e0154461. doi: 10.1371/journal.pone.0154461

64. Baraniak I, Kropff B, Ambrose L, McIntosh M, McLean GR, Pichon S, et al. Protection from cytomegalovirus viremia following glycoprotein B vaccination is not dependent on neutralizing antibodies. Proc Natl Acad Sci USA. (2018) 115:6273-8. doi: 10.1073/pnas.1800224115

65. Nelson CS, Huffman T, Jenks JA, Cisneros de la Rosa E, Xie G, Vandergrift $\mathrm{N}$, et al. HCMV glycoprotein B subunit vaccine efficacy mediated by nonneutralizing antibody effector functions. Proc Natl Acad Sci USA. (2018) 115:6267-72. doi: 10.1073/pnas.1800177115

66. Barouch DH, Stephenson KE, Borducchi EN, Smith K, Stanley K, McNally AG, et al. Protective efficacy of a global HIV-1 mosaic vaccine against heterologous SHIV challenges in rhesus monkeys. Cell. (2013) 155:531-9. doi: 10.1016/j.cell.2013.09.061

67. Barouch DH, Alter G, Broge T, Linde C, Ackerman ME, Brown EP, et al. Protective efficacy of adenovirus/protein vaccines against SIV challenges in rhesus monkeys. Science. (2015) 349:320-4. doi: 10.1126/science.aab3886

68. Zaiss AK, Vilaysane A, Cotter MJ, Clark SA, Meijndert HC, Colarusso $\mathrm{P}$, et al. Antiviral antibodies target adenovirus to phagolysosomes and amplify the innate immune response. J Immunol. (2009) 182:7058-68. doi: 10.4049/jimmunol.0804269

69. Vogt MR, Dowd KA, Engle M, Tesh RB, Johnson S, Pierson TC, et al. Poorly neutralizing cross-reactive antibodies against the fusion loop of West Nile virus envelope protein protect in vivo via Fcgamma receptor and complement-dependent effector mechanisms. J Virol. (2011) 85:11567-80. doi: 10.1128/JVI.05859-11

70. McCullough KC, Parkinson D, Crowther JR. Opsonization-enhanced phagocytosis of foot-and-mouth disease virus. Immunology. (1988) 65:18791.

71. Quattrocchi V, Langellotti C, Pappalardo JS, Olivera V, Di Giacomo S, van Rooijen N, et al. Role of macrophages in early protective immune responses induced by two vaccines against foot and mouth disease. Antiviral Res. (2011) 92:262-70. doi: 10.1016/j.antiviral.2011.08.007

72. Faden H, Kaul TN, Ogra PL. Activation of oxidative and arachidonic acid metabolism in neutrophils by respiratory syncytial virus antibody complexes: possible role in disease. J Infect Dis. (1983) 148:110-6. doi: $10.1093 /$ infdis/148.1.110 
73. Arnold R, Werner F, Humbert B, Werchau H, Konig W. Effect of respiratory syncytial virus-antibody complexes on cytokine (IL-8, IL-6, TNFalpha) release and respiratory burst in human granulocytes. Immunology. (1994) 82:184-91.

74. Kimpen JL, Garofalo R, Welliver RC, Fujihara K, Ogra PL. An ultrastructural study of the interaction of human eosinophils with respiratory syncytial virus. Pediatr Allergy Immunol. (1996) 7:48-53. doi: 10.1111/j.1399-3038.1996.tb00105.x

75. Bukreyev A, Yang L, Collins PL. The secreted G protein of human respiratory syncytial virus antagonizes antibody-mediated restriction of replication involving macrophages and complement. J Virol. (2012) 86:10880-4. doi: 10.1128/JVI.01162-12

76. Borsos T, Rapp HJ. Complement fixation on cell surfaces by $19 \mathrm{~S}$ and $7 \mathrm{~S}$ antibodies. Science. (1965) 150:505-6. doi: 10.1126/science.150.3695.505

77. Diebolder CA, Beurskens FJ, de Jong RN, Koning RI, Strumane K, Lindorfer MA, et al. Complement is activated by IgG hexamers assembled at the cell surface. Science. (2014) 343:1260-3. doi: 10.1126/science.1248943

78. Merle NS, Church SE, Fremeaux-Bacchi V, Roumenina LT. Complement system part I - molecular mechanisms of activation and regulation. Front Immunol. (2015) 6:262. doi: 10.3389/fimmu.2015.00262

79. Merle NS, Noe R, Halbwachs-Mecarelli L, Fremeaux-Bacchi V, Roumenina LT. Complement system part II: role in immunity. Front Immunol. (2015) 6:257. doi: 10.3389/fimmu.2015.00257

80. Hebell T, Ahearn JM, Fearon DT. Suppression of the immune response by a soluble complement receptor of B lymphocytes. Science. (1991) 254:102-5. doi: 10.1126/science. 1718035

81. Gonzalez SF, Lukacs-Kornek V, Kuligowski MP, Pitcher LA, Degn SE, Turley SJ, et al. Complement-dependent transport of antigen into B cell follicles. $J$ Immunol. (2010) 185:2659-64. doi: 10.4049/jimmunol.1000522

82. Mehlhop E, Nelson S, Jost CA, Gorlatov S, Johnson S, Fremont DH, et al. Complement protein $\mathrm{Clq}$ reduces the stoichiometric threshold for antibodymediated neutralization of West Nile virus. Cell Host Microbe. (2009) 6:38191. doi: 10.1016/j.chom.2009.09.003

83. Wu Y, Cho M, Shore D, Song M, Choi J, Jiang T, et al. A potent broad-spectrum protective human monoclonal antibody crosslinking two haemagglutinin monomers of influenza A virus. Nat Commun. (2015) 6:7708. doi: $10.1038 /$ ncomms8708

84. Benhnia MR, McCausland MM, Laudenslager J, Granger SW, Rickert S, Koriazova L, et al. Heavily isotype-dependent protective activities of human antibodies against vaccinia virus extracellular virion antigen B5. J Virol. (2009) 83:12355-67. doi: 10.1128/JVI.01593-09

85. Li F, Freed DC, Tang A, Rustandi RR, Troutman MC, Espeseth AS, et al. Complement enhances in vitro neutralizing potency of antibodies to human cytomegalovirus glycoprotein $\mathrm{B}(\mathrm{gB})$ and immune sera induced by gB/MF59 vaccination. NPJ Vacc. (2017) 2:36. doi: 10.1038/s41541-017-0038-0

86. Churdboonchart V, Bhamarapravati N, Futrakul P. Crossed immunoelectrophoresis for the detection of split products of the third complement in dengue hemorrhagic fever. I. Observations in patients' plasma. Am J Trop Med Hyg. (1983) 32:569-76. doi: 10.4269/ajtmh.1983.32.569

87. Nascimento EJ, Silva AM, Cordeiro MT, Brito CA, Gil LH, BragaNeto $U$, et al. Alternative complement pathway deregulation is correlated with dengue severity. PLoS ONE. (2009) 4:e6782. doi: 10.1371/journal.pone.0006782

88. Senaldi G, Peakman M, McManus T, Davies ET, Tee DE, Vergani D. Activation of the complement system in human immunodeficiency virus infection: relevance of the classical pathway to pathogenesis and disease severity. J Infect Dis. (1990) 162:1227-32. doi: 10.1093/infdis/162.6.1227

89. Fust G, Toth FD, Kiss J, Ujhelyi E, Nagy I, Banhegyi D. Neutralizing and enhancing antibodies measured in complement-restored serum samples from HIV-1-infected individuals correlate with immunosuppression and disease. AIDS. (1994) 8:603-9. doi: 10.1097/00002030-19940500000005

90. Kaul TN, Welliver RC, Ogra PL. Appearance of complement components and immunoglobulins on nasopharyngeal epithelial cells following naturally acquired infection with respiratory syncytial virus. J Med Virol. (1982) 9:149-58. doi: 10.1002/jmv.1890090210
91. Kaul TN, Welliver RC, Ogra PL. Comparison of fluorescent-antibody, neutralizing-antibody, and complement-enhanced neutralizing-antibody assays for detection of serum antibody to respiratory syncytial virus. J Clin Microbiol. (1981) 13:957-62.

92. Kruijsen D, Bakkers MJ, van Uden NO, Viveen MC, van der Sluis TC, Kimpen JL, et al. Serum antibodies critically affect virus-specific CD4+/CD8+ T cell balance during respiratory syncytial virus infections. $J$ Immunol. (2010) 185:6489-98. doi: 10.4049/jimmunol.1002645

93. Melendi GA, Hoffman SJ, Karron RA, Irusta PM, Laham FR, Humbles A, et al. C5 modulates airway hyperreactivity and pulmonary eosinophilia during enhanced respiratory syncytial virus disease by decreasing C3a receptor expression. J Virol. (2007) 81:991-9. doi: 10.1128/JVI.01783-06

94. Bera MM, Lu B, Martin TR, Cui S, Rhein LM, Gerard C, et al. Th17 cytokines are critical for respiratory syncytial virus-associated airway hyperreponsiveness through regulation by complement C3a and tachykinins. J Immunol. (2011) 187:4245-55. doi: 10.4049/jimmunol.1101789

95. Hu X, Li X, Hu C, Qin L, He R, Luo L, et al. Respiratory Syncytial Virus Exacerbates OVA-mediated asthma in mice through C5a-C5aR regulating CD4(+)T cells Immune Responses. Sci Rep. (2017) 7:15207. doi: 10.1038/s41598-017-15471-w

96. Bradley T, Pollara J, Santra S, Vandergrift N, Pittala S, Bailey-Kellogg $\mathrm{C}$, et al. Pentavalent HIV-1 vaccine protects against simian-human immunodeficiency virus challenge. Nat Commun. (2017) 8:15711. doi: 10.1038/ncomms15711

97. Nimmerjahn F, Ravetch JV. Fcgamma receptors: old friends and new family members. Immunity. (2006) 24:19-28. doi: 10.1016/j.immuni.2005.11.010

98. Nimmerjahn F, Ravetch JV. Anti-inflammatory actions of intravenous immunoglobulin. Annu Rev Immunol. (2008) 26:513-33. doi: 10.1146/annurev.immunol.26.021607.090232

99. Pearse RN, Kawabe T, Bolland S, Guinamard R, Kurosaki T, Ravetch JV. SHIP recruitment attenuates Fc gamma RIIB-induced B cell apoptosis. Immunity. (1999) 10:753-60. doi: 10.1016/S1074-7613(00)80074-6

100. Bolland S, Ravetch JV. Spontaneous autoimmune disease in $\mathrm{Fc}$ (gamma)RIIB-deficient mice results from strain-specific epistasis. Immunity. (2000) 13:277-85. doi: 10.1016/S1074-7613(00)00027-3

101. Wang TT, Maamary J, Tan GS, Bournazos S, Davis CW, Krammer F, et al. Anti-HA glycoforms drive B cell affinity selection and determine influenza vaccine efficacy. Cell. (2015) 162:160-9. doi: 10.1016/j.cell.2015.06.026

102. Amigorena S, Salamero J, Davoust J, Fridman WH, Bonnerot C. Tyrosinecontaining motif that transduces cell activation signals also determines internalization and antigen presentation via type III receptors for IgG. Nature. (1992) 358:337-41. doi: 10.1038/358337a0

103. Boruchov AM, Heller G, Veri MC, Bonvini E, Ravetch JV, Young JW. Activating and inhibitory IgG Fc receptors on human DCs mediate opposing functions. J Clin Invest. (2005) 115:2914-23. doi: 10.1172/JCI24772

104. Dhodapkar KM, Kaufman JL, Ehlers M, Banerjee DK, Bonvini E, Koenig $S$, et al. Selective blockade of inhibitory Fcgamma receptor enables human dendritic cell maturation with IL-12p70 production and immunity to antibody-coated tumor cells. Proc Natl Acad Sci USA. (2005) 102:2910-5. doi: 10.1073/pnas.0500014102

105. Dhodapkar KM, Banerjee D, Connolly J, Kukreja A, Matayeva E, Veri MC, et al. Selective blockade of the inhibitory Fcgamma receptor (FcgammaRIIB) in human dendritic cells and monocytes induces a type I interferon response program. J Exp Med. (2007) 204:1359-69. doi: 10.1084/jem.20062545

106. Anderson CF, Mosser DM. Cutting edge: biasing immune responses by directing antigen to macrophage Fc gamma receptors. J Immunol. (2002) 168:3697-701. doi: 10.4049/jimmunol.168.8.3697

107. Kaul TN, Faden H, Ogra PL. Effect of respiratory syncytial virus and virusantibody complexes on the oxidative metabolism of human neutrophils. Infect Immun. (1981) 32:649-54.

108. Everard ML, Swarbrick A, Wrightham M, McIntyre J, Dunkley C, James PD, et al. Analysis of cells obtained by bronchial lavage of infants with respiratory syncytial virus infection. Arch Dis Child. (1994) 71:428-32. doi: 10.1136/adc.71.5.428

109. Bataki EL, Evans GS, Everard ML. Respiratory syncytial virus and neutrophil activation. Clin Exp Immunol. (2005) 140:470-7. doi: 10.1111/j.1365-2249.2005.02780.x 
110. Gomez RS, Ramirez BA, Cespedes PF, Cautivo KM, Riquelme SA, Prado $\mathrm{CE}$, et al. Contribution of $\mathrm{Fc} \gamma$ receptors to human respiratory syncytial virus pathogenesis and the impairment of T cell activation by dendritic cells. Immunology. (2015) 147:55-72. doi: 10.1111/imm.12541

111. Schijf MA, Lukens MV, Kruijsen D, van Uden NO, Garssen J, Coenjaerts FE, et al. Respiratory syncytial virus induced type I IFN production by pDC is regulated by RSV-infected airway epithelial cells, RSV-exposed monocytes and virus specific antibodies. PLOS ONE. (2013) 8:e81695. doi: 10.1371/journal.pone.0081695

112. Vissers M, Schreurs I, Jans J, Heldens J, de Groot R, de Jonge MI, et al. Antibodies enhance CXCL10 production during RSV infection of infant and adult immune cells. Cytokine. (2015) 76:458-64. doi: 10.1016/j.cyto.2015.07.024

113. Ichikawa A, Kuba K, Morita M, Chida S, Tezuka H, Hara H, et al. CXCL10CXCR3 enhances the development of neutrophil-mediated fulminant lung injury of viral and nonviral origin. Am J Respir Crit Care Med. (2013) 187:65-77. doi: 10.1164/rccm.201203-0508OC

114. Halstead SB, Mahalingam S, Marovich MA, Ubol S, Mosser DM. Intrinsic antibody-dependent enhancement of microbial infection in macrophages: disease regulation by immune complexes. Lancet Infect Dis. (2010) 10:71222. doi: 10.1016/S1473-3099(10)70166-3

115. Taylor A, Foo SS, Bruzzone R, Vu Dinh L, King NJ, Mahalingam S. Fc receptors in antibody-dependent enhancement of viral infections. Immunol Rev. (2015) 268:340-64. doi: 10.1111/imr.12367

116. Krilov LR, Anderson LJ, Marcoux L, Bonagura VR, Wedgwood JF. Antibody-mediated enhancement of respiratory syncytial virus infection in two monocyte/macrophage cell lines. J Infect Dis. (1989) 160:777-82. doi: 10.1093/infdis/160.5.777

117. Osiowy C, Horne D, Anderson R. Antibody-dependent enhancement of respiratory syncytial virus infection by sera from young infants. Clin Diagn Lab Immunol. (1994) 1:670-77.

118. Gimenez HB, Chisholm S, Dornan J, Cash P. Neutralizing and enhancing activities of human respiratory syncytial virus-specific antibodies. Clin Diagn Lab Immunol. (1996) 3:280-6.

119. van Erp EA, van Kasteren PB, Guichelaar T, Ahout IML, de Haan CAM, Luytjes $\mathrm{W}$, et al. In vitro enhancement of respiratory syncytial virus infection by maternal antibodies does not explain disease severity in infants. J Virol. (2017) 91:e00851-17. doi: 10.1128/JVI.00851-17

120. van Erp EA, Feyaerts D, Duijst M, Mulder HL, Wicht O, Luytjes W, et al. Respiratory syncytial virus (RSV) infects primary neonatal and adult natural killer cells and affects their antiviral effector function. J Infect Dis. (2018) 219:723-33. doi: 10.1093/infdis/jiy566

121. Mascola JR, Mathieson BJ, Zack PM, Walker MC, Halstead SB, Burke DS. Summary report: workshop on the potential risks of antibody-dependent enhancement in human HIV vaccine trials. AIDS Res Hum Retroviruses. (1993) 9:1175-84. doi: 10.1089/aid.1993.9.1175

122. Polack FP. Atypical measles and enhanced respiratory syncytial virus disease (ERD) made simple. Pediatr Res. (2007) 62:111-5. doi: 10.1203/PDR.0b013e3180686ce0

123. Skowronski DM, De Serres G, Crowcroft NS, Janjua NZ, Boulianne N, Hottes TS, et al. Association between the 2008-09 seasonal influenza vaccine and pandemic H1N1 illness during Spring-Summer 2009: four observational studies from Canada. PLoS Med. (2010) 7:e1000258. doi: 10.1371/journal.pmed.1000258

124. Katzelnick LC, Gresh L, Halloran ME, Mercado JC, Kuan G, Gordon A, et al. Antibody-dependent enhancement of severe dengue disease in humans. Science. (2017) 358:929-32. doi: 10.1126/science.aan6836

125. Murphy BR, Sotnikov AV, Lawrence LA, Banks SM, Prince GA. Enhanced pulmonary histopathology is observed in cotton rats immunized with formalin-inactivated respiratory syncytial virus (RSV) or purified F glycoprotein and challenged with RSV 3-6 months after immunization. Vaccine. (1990) 8:497-502.

126. Murphy BR, Sotnikov A, Paradiso PR, Hildreth SW, Jenson AB, Baggs $\mathrm{RB}$, et al. Immunization of cotton rats with the fusion (F) and large $(\mathrm{G})$ glycoproteins of respiratory syncytial virus (RSV) protects against RSV challenge without potentiating RSV disease. Vaccine. (1989) 7:533-40.

127. Schneider-Ohrum K, Cayatte C, Bennett AS, Rajani GM, McTamney P, Nacel K, et al. Immunization with low doses of recombinant postfusion or prefusion respiratory syncytial virus $\mathrm{F}$ primes for vaccine-enhanced disease in the cotton rat model independently of the presence of a Th1-Biasing (GLA-SE) or Th2-biasing (alum) adjuvant. J Virol. (2017) 91:e02180-16. doi: 10.1128/jvi.02180-16

128. Aleyd E, Heineke MH, van Egmond M. The era of the immunoglobulin A Fc receptor Fc $\alpha$ RI; its function and potential as target in disease. Immunol Rev. (2015) 268:123-38. doi: 10.1111/imr.12337

129. Vidarsson G, Dekkers G, Rispens T. IgG subclasses and allotypes: from structure to effector functions. Front Immunol. (2014) 5:520. doi: 10.3389/fimmu.2014.00520

130. Bruhns P, Iannascoli B, England P, Mancardi DA, Fernandez N, Jorieux $S$, et al. Specificity and affinity of human Fcgamma receptors and their polymorphic variants for human IgG subclasses. Blood. (2009) 113:3716-25. doi: 10.1182/blood-2008-09-179754

131. Jennewein MF, Alter G. The immunoregulatory roles of antibody glycosylation. Trends Immunol. (2017) 38:358-72. doi: 10.1016/j.it.2017.02.004

132. Pone EJ, Zhang J, Mai T, White CA, Li G, Sakakura JK, et al. BCRsignalling synergizes with TLR-signalling for induction of AID and immunoglobulin class-switching through the non-canonical NF-kappaB pathway. Nat Commun. (2012) 3:767. doi: 10.1038/ncomms1769

133. Wagner DK, Graham BS, Wright PF, Walsh EE, Kim HW, Reimer CB, et al. Serum immunoglobulin $\mathrm{G}$ antibody subclass responses to respiratory syncytial virus $\mathrm{F}$ and $\mathrm{G}$ glycoproteins after primary infection. J Clin Microbiol. (1986) 24:304-6.

134. Watt PJ, Zardis M, Lambden PR. Age related IgG subclass response to respiratory syncytial virus fusion protein in infected infants. Clin Exp Immunol. (1986) 64:503-9.

135. Ferrante A, Beard LJ, Feldman RG. IgG subclass distribution of antibodies to bacterial and viral antigens. Pediatr Infect Dis J. (1990) 9(8 Suppl.):S16-24. doi: 10.1097/00006454-199008001-00004

136. Bruggemann M, Williams GT, Bindon CI, Clark MR, Walker MR, Jefferis $\mathrm{R}$, et al. Comparison of the effector functions of human immunoglobulins using a matched set of chimeric antibodies. J Exp Med. (1987) 166:1351-61. doi: 10.1084/jem.166.5.1351

137. Tay MZ, Liu P, Williams LD, McRaven MD, Sawant S, Gurley TC, et al. Antibody-mediated internalization of infectious HIV-1 virions differs among antibody isotypes and subclasses. PLoS Pathog. (2016) 12:e1005817. doi: 10.1371/journal.ppat.1005817

138. Stapleton NM, Andersen JT, Stemerding AM, Bjarnarson SP, Verheul RC, Gerritsen J, et al. Competition for FcRn-mediated transport gives rise to short half-life of human IgG3 and offers therapeutic potential. Nat Commun. (2011) 2:599. doi: 10.1038/ncomms1608

139. Bournazos S, Ravetch JV. Fc $\gamma$ receptor function and the design of vaccination strategies. Immunity. (2017) 47:224-33. doi: 10.1016/j.immuni.2017.07.009

140. Chung AW, Ghebremichael M, Robinson H, Brown E, Choi I, Lane S, et al. Polyfunctional Fc-effector profiles mediated by IgG subclass selection distinguish RV144 and VAX003 vaccines. Sci Transl Med. (2014) 6:228ra238. doi: 10.1126/scitranslmed.3007736

141. Habibi MS, Jozwik A, Makris S, Dunning J, Paras A, DeVincenzo JP, et al. Impaired Antibody-mediated protection and defective IgA B-cell memory in experimental infection of adults with respiratory syncytial virus. Am J Respir Crit Care Med. (2015) 191:1040-9. doi: 10.1164/rccm.201412-2256OC

142. Walsh EE, Falsey AR. Humoral and mucosal immunity in protection from natural respiratory syncytial virus infection in adults. J Infect Dis. (2004) 190:373-8. doi: 10.1086/421524

143. Leschinskaya NP, Pokrovskaya EE, Kantorovitch EA, Grigorjeva SK, Shvartsman Ya S. Ontogenesis of the formation of secretory antibodies to respiratory syncytial (RS) virus. Epidemiol Infect. (1988) 101:565-75.

144. Jacobino SR, Nederend M, Reijneveld JF, Augustijn D, Jansen JHM, Meeldijk $\mathrm{J}$, et al. Reformatting palivizumab and motavizumab from IgG to human IgA impairs their efficacy against RSV infection in vitro and in vivo. MAbs. (2018) 10:453-62. doi: 10.1080/19420862.2018.1433974

145. Welliver RC, Wong DT, Sun M, Middleton E Jr, Vaughan RS, et al. The development of respiratory syncytial virus-specific $\operatorname{IgE}$ and the release of histamine in nasopharyngeal secretions after infection. N Engl J Med. (1981) 305:841-6. doi: 10.1056/NEJM1981100 83051501 
146. Russi JC, Delfraro A, Borthagaray MD, Velazquez B, Garcia-Barreno B, Hortal M. Evaluation of immunoglobulin E-specific antibodies and viral antigens in nasopharyngeal secretions of children with respiratory syncytial virus infections. J Clin Microbiol. (1993) 31:819-23.

147. Welliver RC, Duffy L. The relationship of RSV-specific immunoglobulin E antibody responses in infancy, recurrent wheezing, and pulmonary function at age 7-8 years. Pediatr Pulmonol. (1993) 15:19-27. doi: 10.1002/ppul.1950150104

148. Smith-Norowitz TA, Mandal M, Joks R, Norowitz LT, Weaver D, Durkin $\mathrm{HG}$, et al. IgE anti-respiratory syncytial virus antibodies detected in serum of pediatric patients with asthma. Hum Immunol. (2015) 76:519-24. doi: 10.1016/j.humimm.2015.06.002

149. Dakhama A, Lee YM, Ohnishi H, Jing X, Balhorn A, Takeda K, et al. Virusspecific IgE enhances airway responsiveness on reinfection with respiratory syncytial virus in newborn mice. J Allergy Clin Immunol. (2009) 123:138145.e135. doi: 10.1016/j.jaci.2008.10.012

150. Welliver RC, Kaul TN, Ogra PL. The appearance of cell-bound IgE in respiratory-tract epithelium after respiratory-syncytial-virus infection. $N$ Engl J Med. (1980) 303:1198-202. doi: 10.1056/NEJM198011203032103

151. Welliver RC, Sun M, Rinaldo D, Ogra PL. Predictive value of respiratory syncytial virus-specific IgE responses for recurrent wheezing following bronchiolitis. J Pediatr. (1986) 109:776-80. doi: 10.1016/S0022-3476(86)80692-8

152. Lee Chung H, Jang YY. High serum IgE level in the children with acute respiratory syncytial virus infection is associated with severe disease. J Allergy Clin Immunol. (2016) 137:AB110. doi: 10.1016/j.jaci.2015.12.486

153. Wagner DK, Nelson DL, Walsh EE, Reimer CB, Henderson FW, Murphy BR. Differential immunoglobulin G subclass antibody titers to respiratory syncytial virus $\mathrm{F}$ and $\mathrm{G}$ glycoproteins in adults. J Clin Microbiol. (1987) 25:748-50.

154. Wagner DK, Muelenaer P, Henderson FW, Snyder MH, Reimer CB, Walsh EE, et al. Serum immunoglobulin $\mathrm{G}$ antibody subclass response to respiratory syncytial virus $\mathrm{F}$ and $\mathrm{G}$ glycoproteins after first, second, and third infections. J Clin Microbiol. (1989) 27:589-92.

155. Jounai N, Yoshioka M, Tozuka M, Inoue K, Oka T, Miyaji K, et al. Agespecific profiles of antibody responses against respiratory syncytial virus infection. EBioMed. (2017) 16:124-35. doi: 10.1016/j.ebiom.2017.01.014

156. Stevens TL, Bossie A, Sanders VM, Fernandez-Botran R, Coffman RL, Mosmann TR, et al. Regulation of antibody isotype secretion by subsets of antigen-specific helper T cells. Nature. (1988) 334:255-8. doi: $10.1038 / 334255 \mathrm{a} 0$

157. Tregoning JS, Wang BL, McDonald JU, Yamaguchi Y, Harker JA, Goritzka M, et al. Neonatal antibody responses are attenuated by interferon- $\gamma$ produced by NK and T cells during RSV infection. Proc Natl Acad Sci USA. (2013) 110:5576-81. doi: 10.1073/pnas.1214247110

158. Reuman PD, Keely SP, Schiff GM. Comparison of class and subclass antibody response to live and UV-inactivated RSV administered intranasally in mice. J Med Virol. (1991) 35:198-205. doi: 10.1002/jmv.1890350310

159. Hiatt A, Bohorova N, Bohorov O, Goodman C, Kim D, Pauly MH, et al. Glycan variants of a respiratory syncytial virus antibody with enhanced effector function and in vivo efficacy. Proc Natl Acad Sci USA. (2014) 111:5992-7. doi: 10.1073/pnas.1402458111

160. Umana P, Jean-Mairet J, Moudry R, Amstutz H, Bailey JE. Engineered glycoforms of an antineuroblastoma IgG1 with optimized antibodydependent cellular cytotoxic activity. Nat Biotechnol. (1999) 17:176-80. doi: $10.1038 / 6179$

161. Shields RL, Lai J, Keck R, O’Connell LY, Hong K, Meng YG, et al. Lack of fucose on human IgG1 N-linked oligosaccharide improves binding to human Fcgamma RIII and antibody-dependent cellular toxicity. J Biol Chem. (2002) 277:26733-40. doi: 10.1074/jbc.M202069200

162. Ferrara C, Grau S, Jager C, Sondermann P, Brunker P, Waldhauer I, et al. Unique carbohydrate-carbohydrate interactions are required for high affinity binding between FcgammaRIII and antibodies lacking core fucose. Proc Natl Acad Sci USA. (2011) 108:12669-74. doi: 10.1073/pnas.1108455108

163. Forthal DN, Gach JS, Landucci G, Jez J, Strasser R, Kunert R, et al. Fcglycosylation influences $\mathrm{Fc} \gamma$ receptor binding and cell-mediated anti-HIV activity of monoclonal antibody 2G12. J Immunol. (2010) 185:6876-82. doi: 10.4049/jimmunol.1002600

164. Zeitlin L, Pettitt J, Scully C, Bohorova N, Kim D, Pauly M, et al. Enhanced potency of a fucose-free monoclonal antibody being developed as an Ebola virus immunoprotectant. Proc Natl Acad Sci USA. (2011) 108:20690-4. doi: $10.1073 /$ pnas. 1108360108

165. Junttila TT, Parsons K, Olsson C, Lu Y, Xin Y, Theriault J, et al. Superior in vivo efficacy of afucosylated trastuzumab in the treatment of HER2-amplified breast cancer. Cancer Res. (2010) 70:4481-9. doi: 10.1158/0008-5472.CAN-09-3704

166. Dalle S, Reslan L, Besseyre de Horts T, Herveau S, Herting F, Plesa A, et al. Preclinical studies on the mechanism of action and the anti-lymphoma activity of the novel anti-CD20 antibody GA101. Mol Cancer Ther. (2011) 10:178-85. doi: 10.1158/1535-7163.MCT-10-0385

167. Kaneko Y, Nimmerjahn F, Ravetch JV. Anti-inflammatory activity of immunoglobulin G resulting from Fc sialylation. Science. (2006) 313:670-3. doi: 10.1126/science.1129594

168. Dekkers G, Treffers L, Plomp R, Bentlage AEH, de Boer M, Koeleman CAM, et al. Decoding the human immunoglobulin G-Glycan repertoire reveals a spectrum of Fc-receptor- and complement-mediated-effector activities. Front Immunol. (2017) 8:877. doi: 10.3389/fimmu.2017.00877

169. Maverakis E, Kim K, Shimoda M, Gershwin ME, Patel F, Wilken R, et al. Glycans in the immune system and The Altered Glycan Theory of Autoimmunity: a critical review. J Autoimmun. (2015) 57:1-13. doi: 10.1016/j.jaut.2014.12.002

170. Rook GA, Steele J, Brealey R, Whyte A, Isenberg D, Sumar N, et al. Changes in IgG glycoform levels are associated with remission of arthritis during pregnancy. J Autoimmun. 4:779-94. doi: 10.1016/0896-8411(91)90173-A

171. van de Geijn FE, Wuhrer M, Selman MH, Willemsen SP, de Man YA, Deelder AM, et al. Immunoglobulin G galactosylation and sialylation are associated with pregnancy-induced improvement of rheumatoid arthritis and the postpartum flare: results from a large prospective cohort study. Arthritis Res Ther. (2009) 11:R193. doi: 10.1186/ar2892

172. Mahan AE, Jennewein MF, Suscovich T, Dionne K, Tedesco J, Chung AW, et al. Antigen-specific antibody glycosylation is regulated via vaccination. PLoS Pathog. (2016) 12:e1005456. doi: 10.1371/journal.ppat.1005456

173. Shim H. One target, different effects: a comparison of distinct therapeutic antibodies against the same targets. Exp Mol Med. (2011) 43:539-49. doi: 10.3858/emm.2011.43.10.063

174. He W, Tan GS, Mullarkey CE, Lee AJ, Lam MM, Krammer F, et al. Epitope specificity plays a critical role in regulating antibody-dependent cellmediated cytotoxicity against influenza A virus. Proc Natl Acad Sci USA. (2016) 113:11931-6. doi: 10.1073/pnas.1609316113

175. Cleary KLS, Chan HTC, James S, Glennie MJ, Cragg MS. Antibody distance from the cell membrane regulates antibody effector mechanisms. J Immunol. (2017) 198:3999-4011. doi: 10.4049/jimmunol.1601473

176. Jegaskanda S, Job ER, Kramski M, Laurie K, Isitman G, de Rose R, et al. Cross-reactive influenza-specific antibody-dependent cellular cytotoxicity antibodies in the absence of neutralizing antibodies. I Immunol. (2013) 190:1837-48. doi: 10.4049/jimmunol.1201574

177. Bakalar MH, Joffe AM, Schmid EM, Son S, Podolski M, Fletcher DA. Size-dependent segregation controls macrophage phagocytosis of antibody-opsonized targets. Cell. (2018) 174:131-142.e113. doi: 10.1016/j.cell.2018.05.059

178. Connors M, Collins PL, Firestone CY, Murphy BR. Respiratory syncytial virus (RSV) F, G, M2 (22K), and N proteins each induce resistance to RSV challenge, but resistance induced by $\mathrm{M} 2$ and $\mathrm{N}$ proteins is relatively short-lived. J Virol. (1991) 65:1634-7.

179. Akerlind-Stopner B, Hu A, Mufson MA, Utter G, Norrby E. Antibody responses of children to the C-terminal peptide of the $\mathrm{SH}$ protein of respiratory syncytial virus and the immunological characterization of this protein. J Med Virol. (1993) 40:112-20. doi: 10.1002/jmv.18904 00207

180. Kumari S, Crim RL, Kulkarni A, Audet SA, Mdluli T, Murata H, et al. Development of a luciferase immunoprecipitation system assay to detect IgG antibodies against human respiratory syncytial virus nucleoprotein. Clin Vaccine Immunol. (2014) 21:383-90. doi: 10.1128/CVI.00594-13

181. Schepens B, Sedeyn K, Vande Ginste L, De Baets S, Schotsaert M, Roose K, et al. Protection and mechanism of action of a novel human respiratory syncytial virus vaccine candidate based on the extracellular domain of small hydrophobic protein. EMBO Mol Med. (2014) 6:1436-54. doi: 10.15252/emmm.201404005

182. Capella C, Chaiwatpongsakorn S, Gorrell E, Risch ZA, Ye F, Mertz SE, et al. Prefusion F, postfusion F, G antibodies and disease severity in infants and 
young children with acute respiratory syncytial virus infection. J Infect Dis. (2017). doi: 10.1093/infdis/jix489

183. Gilman MS, Castellanos CA, Chen M, Ngwuta JO, Goodwin E, Moin SM, et al. Rapid profiling of RSV antibody repertoires from the memory B cells of naturally infected adult donors. Sci Immunol. (2016) 1:eaaj1879. doi: 10.1126/sciimmunol.aaj1879

184. Mousa JJ, Kose N, Matta P, Gilchuk P, Crowe JE Jr. A novel prefusion conformation-specific neutralizing epitope on the respiratory syncytial virus fusion protein. Nat Microbiol. (2017) 2:16271. doi: 10.1038/nmicrobiol.2016.271

185. Ngwuta JO, Chen M, Modjarrad K, Joyce MG, Kanekiyo M, Kumar A, et al. Prefusion F-specific antibodies determine the magnitude of RSV neutralizing activity in human sera. Sci Transl Med. (2015) 7:309ra162. doi: 10.1126/scitranslmed.aac4241

186. Fedechkin SO, George NL, Wolff JT, Kauvar LM, DuBois RM. Structures of respiratory syncytial virus $\mathrm{G}$ antigen bound to broadly neutralizing antibodies. Sci Immunol. (2018) 3:eaar3534. doi: 10.1126/sciimmunol.aar3534

187. Johnson SM, McNally BA, Ioannidis I, Flano E, Teng MN, Oomens $\mathrm{AG}$, et al. Respiratory syncytial virus uses CX3CR1 as a receptor on primary human airway epithelial cultures. PLoS Pathog. (2015) 11:e1005318. doi: 10.1371/journal.ppat.1005318

188. Boyoglu-Barnum S, Todd SO, Chirkova T, Barnum TR, Gaston KA, Haynes LM, et al. An anti-G protein monoclonal antibody treats RSV disease more effectively than an anti-F monoclonal antibody in BALB/c mice. Virology. (2015) 483:117-25. doi: 10.1016/j.virol.2015.02.035

189. Tripp RA, Jones LP, Haynes LM, Zheng H, Murphy PM, Anderson LJ. CX3C chemokine mimicry by respiratory syncytial virus G glycoprotein. Nat Immunol. (2001) 2:732-8. doi: 10.1038/90675

190. Fuentes S, Coyle EM, Beeler J, Golding H, Khurana S. Antigenic fingerprinting following primary RSV infection in young children identifies novel antigenic sites and reveals unlinked evolution of human antibody repertoires to fusion and attachment glycoproteins. PLoS Pathog. (2016) 12:e1005554. doi: 10.1371/journal.ppat.1005554

191. Goodier MR, Lusa C, Sherratt S, Rodriguez-Galan A, Behrens R, Riley EM. Sustained immune complex-mediated reduction in CD16 expression after vaccination regulates NK cell function. Front Immunol. (2016) 7:384. doi: 10.3389/fimmu.2016.00384

192. van Egmond M, Vidarsson G, Bakema JE. Cross-talk between pathogen recognizing Toll-like receptors and immunoglobulin Fc receptors in immunity. Immunol Rev. (2015) 268:311-27. doi: 10.1111/imr.12333

193. Bournazos S, Woof JM, Hart SP, Dransfield I. Functional and clinical consequences of $\mathrm{Fc}$ receptor polymorphic and copy number variants. Clin Exp Immunol. (2009) 157:244-54. doi: 10.1111/j.1365-2249.2009.03980.x

194. Warmerdam PA, van de Winkel JG, Gosselin EJ, Capel PJ. Molecular basis for a polymorphism of human Fc gamma receptor II (CD32). J Exp Med. (1990) 172:19-25. doi: 10.1084/jem.172.1.19

195. Salmon JE, Edberg JC, Brogle NL, Kimberly RP. Allelic polymorphisms of human $\mathrm{Fc}$ gamma receptor IIA and $\mathrm{Fc}$ gamma receptor IIIB. Independent mechanisms for differences in human phagocyte function. J Clin Invest. (1992) 89:1274-81. doi: 10.1172/JCI115712

196. Koene HR, Kleijer M, Algra J, Roos D, von dem Borne AE, de Haas M. Fc gammaRIIIa-158V/F polymorphism influences the binding of IgG by natural killer cell Fc gammaRIIIa, independently of the Fc gammaRIIIa-48L/R/H phenotype. Blood. (1997) 90:1109-14.

197. Wu J, Edberg JC, Redecha PB, Bansal V, Guyre PM, Coleman K, et al. A novel polymorphism of FcgammaRIIIa (CD16) alters receptor function and predisposes to autoimmune disease. J Clin Invest. (1997) 100:1059-70. doi: 10.1172/JCI119616

198. Guerrero-Plata A, Ortega E, Gomez B. Persistence of respiratory syncytial virus in macrophages alters phagocytosis and pro-inflammatory cytokine production. Viral Immunol. (2001) 14:19-30. doi: 10.1089/08828240151061347

199. Li X, Kimberly RP. Targeting the Fc receptor in autoimmune disease. Expert Opin Ther Targets. (2014) 18:335-50. doi: 10.1517/14728222.2014.877891
200. Mellor JD, Brown MP, Irving HR, Zalcberg JR, Dobrovic A. A critical review of the role of $\mathrm{Fc}$ gamma receptor polymorphisms in the response to monoclonal antibodies in cancer. J Hematol Oncol. (2013) 6:1. doi: 10.1186/1756-8722-6-1

201. Forthal DN, Gabriel EE, Wang A, Landucci G, Phan TB. Association of Fcy receptor IIIa genotype with the rate of HIV infection after gp120 vaccination. Blood. (2012) 120:2836-42. doi: 10.1182/blood-2012-05-431361

202. Li SS, Gilbert PB, Tomaras GD, Kijak G, Ferrari G, Thomas R, et al. FCGR2C polymorphisms associate with HIV-1 vaccine protection in RV144 trial. $J$ Clin Invest. (2014) 124:3879-90. doi: 10.1172/JCI75539

203. Dettogni RS, Tristao-Sa R, Dos Santos M, da Silva FF, Louro ID. Single nucleotide polymorphisms in immune system genes and their association with clinical symptoms persistence in dengue-infected persons. Hum Immunol. (2015) 76:717-23. doi: 10.1016/j.humimm.2015.09.026

204. Moraru M, Black LE, Muntasell A, Portero F, Lopez-Botet M, Reyburn HT, et al. NK Cell and Ig Interplay in Defense against Herpes Simplex Virus Type 1: epistatic interaction of CD16A and IgG1 allotypes of variable affinities modulates antibody-dependent cellular cytotoxicity and susceptibility to clinical reactivation. J Immunol. (2015) 195:1676-84. doi: 10.4049/jimmunol.1500872

205. Janssen R, Bont L, Siezen CL, Hodemaekers HM, Ermers MJ, Doornbos $\mathrm{G}$, et al. Genetic susceptibility to respiratory syncytial virus bronchiolitis is predominantly associated with innate immune genes. J Infect Dis. (2007) 196:826-34. doi: $10.1086 / 520886$

206. IMpact. Palivizumab, a humanized respiratory syncytial virus monoclonal antibody, reduces hospitalization from respiratory syncytial virus infection in high-risk infants. The IMpact-RSV Study Group. Pediatrics. (1998) 102(3 Pt 1):531-7.

207. Wang D, Cummins C, Bayliss S, Sandercock J, Burls A. Immunoprophylaxis against respiratory syncytial virus (RSV) with palivizumab in children: a systematic review and economic evaluation. Health Technol Assess. (2008) 12:iii, ix-x, 1-86. doi: 10.3310/hta12360

208. Mejias A, Garcia-Maurino C, Rodriguez-Fernandez R, Peeples ME, Ramilo O. Development and clinical applications of novel antibodies for prevention and treatment of respiratory syncytial virus infection. Vaccine. (2017) 35:496-502. doi: 10.1016/j.vaccine.2016.09.026

209. Falloon J, Yu J, Esser MT, Villafana T, Yu L, Dubovsky F, et al. An adjuvanted, postfusion F protein-based vaccine did not prevent respiratory syncytial virus illness in older adults. J Infect Dis. (2017) 216:1362-70. doi: 10.1093/infdis/jix503

210. Tripp RA, Power UF, Openshaw PJM, Kauvar LM. Respiratory syncytial virus: targeting the $\mathrm{G}$ protein provides a new approach for an old problem. $J$ Virol. (2018) 92:e01302-17. doi: 10.1128/JVI.01302-17

211. Boyoglu-Barnum S, Chirkova T, Todd SO, Barnum TR, Gaston KA, Jorquera $\mathrm{P}$, et al. Prophylaxis with a respiratory syncytial virus (RSV) anti-G protein monoclonal antibody shifts the adaptive immune response to RSV rA2line19F infection from Th2 to Th1 in BALB/c mice. J Virol. (2014) 88:1056983. doi: 10.1128/JVI.01503-14

212. Lu LL, Chung AW, Rosebrock TR, Ghebremichael M, Yu WH, Grace PS, et al. A functional role for antibodies in tuberculosis. Cell. (2016) 167:433-43 e414. doi: 10.1016/j.cell.2016.08.072

213. Ackerman ME, Barouch DH, Alter G. Systems serology for evaluation of HIV vaccine trials. Immunol Rev. (2017) 275:262-70. doi: 10.1111/imr.12503

Conflict of Interest Statement: The authors declare that the research was conducted in the absence of any commercial or financial relationships that could be construed as a potential conflict of interest.

Copyright (c) 2019 van Erp, Luytjes, Ferwerda and van Kasteren. This is an openaccess article distributed under the terms of the Creative Commons Attribution License (CC BY). The use, distribution or reproduction in other forums is permitted, provided the original author(s) and the copyright owner(s) are credited and that the original publication in this journal is cited, in accordance with accepted academic practice. No use, distribution or reproduction is permitted which does not comply with these terms. 